Twenty-Second Solentiffid Meeting-Ereventh Scotrish Meeming

\author{
Department of Physiology, University College, Dundee, \\ OCTOBER 7TH, 1944
}

\title{
DIET AND TUBERCULOSIS
}

\author{
Chairman, Dr. W. T. MunRo
}

Dr. W. T. Munro (Fife and Kinross Joint Sanatorium): I am very sensible of the honour you have done me in asking me to preside over the deliberations of The Nutrition Society and I have very real pleasure in coming here. I note I am expected to speak to the subject by way of introduction, and I would like to place before you my views of how we could approach the problem. Diet has such a profound influence on the health of the nation that it is our duty to do all we can to ensure not only that it is sufficient but also that it is correct in every particular for the age of the subject. Much of the ill health which afflicts human populations can be attributed to deficiencies in diet, and we know that defective nutrition is one of the factors which can so alter the physical well being of a tubercle infected individual that he is not able to overcome his initial infection and may readily become a person suffering from some form of localized tuberculosis in later life. The very serious increase in the incidence of tuberculosis in Austria and Poland during the last war bears witness to this fact. The countries which suffered most, and where nutrition was poorest, showed very grave increases in mortality from tuberculosis. I am glad to note that the first communication today, from Dr. Leitch, will touch on these points. I prefer to speak of environmental factors which react unfarourably in the tubercle infected, prevent healing and eventually lead to a breakdown, often in the lungs. These factors are numerous and many may be operative at one time, fatigue, overwork, misuse of leisure, intercurrent illness, repeated pregnancies, defective nutrition and so on, and I fancy defective nutrition is the most important. Certainly the interval between infection and disease is shortest in the homes of the feckless parents. This Society will already have considered war time dietary and I can find little fault with it, but in tuberculosis I think we should consider the subject of nutrition first for the child and then for the adult.

\section{The Child}

In regard to the child two issues appear to me to arise: (1) Prevention of infection, and (2) management of the infected child, which often means prevention of disease after the fact of infection.

(1) In prevention of infection it should be emphasized that milk supplied to schoolchildren and indeed to all children must be free from viable tubercle bacilli. London's milk supply to the extent of 90 per cent. is pasteurized, while Glasgow has 80 per cent. of its supply pasteurized. We know there is little or no pasteurization in rural areas. This is a rural problem, and in rural areas milk should be boiled. The calcium content of milk is $0.7 \mathrm{~g}$. per pint and this is necessary for the growing child.

VOL. 3,1945$]$

155 
(2) Management of the infected child. A child infected by the tubercle bacillus may show this fact in more or less degree. There may be from minimal signs to gross evidence in the lymphatic system or in the viscera. We now know that the spread of the bacillus through the body on infection may bo very wide. Correct and generous dietary can go far towards the countering of infection. In addition to ordinary diet vitamins $A, C$ and $\mathrm{D}$ are necessary.

\section{The Adult}

(1) Prevention. War time dietary is sufficient to maintain health. It has adequate energy value, protein, vitamin and mineral content.

(2) Nutrition and treatment. Here we must consider $(a)$ the favourable case, $(b)$ the febrile case, $(c)$ the patient suffering from the more common sequelae of pulmonary tuberculosis, intestinal and laryngeal ulceration, (d) the patient whose disease is associated with diabetes.

The favourable case requires nothing more than a good, generous diet. The febrile case requires more care in dietary. He may be capricious in his likes and dislikes. Service counts for so much, and too much must not be served at a time. Further, investigation has shown that vitamin C reserves are quickly utilized by the febrile patient and in some cases it is not easy to saturate such a patient with ascorbic acid; vitamin $C$ is necessary to replace depleted reserves. We have found no healing virtue in ascorbic acid but the terminal features of soft, bleeding gums and sore tongue are avoided. Liberal use of ascorbic acid will obviate these unpleasant features. Further, there is evidence that replacement of vitamin $\mathrm{C}$ reserves tends to a retention of the sodium ion and there is a tonic effect. As a plasma level of vitamin $\mathrm{C}$ of $\mathrm{I} \mathrm{mg}$. per $100 \mathrm{ml}$. is approached there is a rise in the serum sodium level towards the normal value of $320 \mathrm{mg}$. per $100 \mathrm{ml}$. serum.

\section{Diet and Tuberculosis: Introductory Review}

\section{Dr. I. Leitch (Imperial Bureau of Animal Nutrition, Bucksburn, Aberdeen)}

There are two distinct aspects of this subject. First, milk is a vehicle of infection and yet so important a food for growth and health that the question is asked, is it better to drink even infected milk than not to drink milk at all? Fortunately the question need not arise in that form. Second, there is evidence, which I propose to outline briefly, that the nature of the diet affects resistance to tuberculosis.

To get the two types of infection into correct perspective, Table 1 (Wilson, 1942) shows what the position is estimated to have been in 1937. The proportion of cases of pulmonary tuberculosis due to bovine bacilli was very small but significantly higher in Scotland than in England and Wales.

The proportion of non-pulmonary tuberculosis due to bovine infection was higher, and came near to 30 per cent. but, altogether, it accounted for only 5.6 per cent. of the total tuberculosis mortality in England and Wales and 11 per cent. in Scotland. It is evident therefore that to make any obvious difference to the total bill of mortality, a considerable increase in bovine tuberculosis would be required. 
TABLE 1

Percentage Due to Bovine Infection of Total Mortality from Tuberculosis

\begin{tabular}{|c|c|c|c|}
\hline Country & Respiratory & Non-respiratory & Both \\
\hline $\begin{array}{l}\text { England and Wales } \\
\text { Scotland }\end{array}$ & $\begin{array}{l}1 \cdot 4 \\
5 \cdot 4\end{array}$ & $\begin{array}{l}27 \cdot 8 \\
29 \cdot 0\end{array}$ & $\begin{array}{r}5 \cdot 6 \\
11 \cdot 0\end{array}$ \\
\hline
\end{tabular}

Let us look next at the historical sequence of events. Tuberculosis has been known clinically for 2000 years, but information regarding its incidence and the toll it takes of human health and life is of recent date. Attempts have been made to assess the weight of its attack in the 17th century (Greenwood, 1935) but it will be sufficient to go back to the more accurately recorded data from 1850 onwards. In Table 2 are presented selected data for four $\mathbf{5}$ year periods.

TABLE 2

Standardized Mortality Rates. Deaths per Million of the Population in England and Wates

\begin{tabular}{c|c|c|c|c|c|c}
\hline \multirow{2}{*}{ Period } & \multicolumn{2}{|c|}{ Respiratory } & \multicolumn{2}{|c|}{ Non-respiratory } & \multicolumn{2}{c}{ Both } \\
\cline { 2 - 6 } & Rate & Per cent. & Rate & Per cent. & Rate & Per cent. \\
\hline $1851-55$ & 2890 & $79 \cdot 4$ & 748 & $20 \cdot 6$ & 3638 & 100 \\
$1901-05$ & 1209 & $69 \cdot 5$ & 531 & $30 \cdot 5$ & 1740 & 100 \\
$1921-25$ & 816 & $76 \cdot 5$ & 250 & $23 \cdot 5$ & 1066 & 100 \\
$1934-38$ & 532 & 79.6 & 136 & $20 \cdot 4$ & 668 & 100 \\
& & & & & & \\
\hline
\end{tabular}

Between the two quinquennia 1851-55 and 1934-38 there has been a reduction of tuberculosis mortality by over 80 per cent., and by almost exactly the same amount for both pulmonary and non-pulmonary forms. The decrease has been remarkably smooth, most rapid round about the time of Koch's identification of the bacillus but probably not on account of that, and has been seriously interrupted only by the last war.

There appears to be no information about bovine tuberculosis until quite recent years and no one appears to have tried to make any estimate of its relative importance at different periods. I have therefore tried to do this, the comparison being suggested by the striking similarity between the percentage distributions of pulmonary and non-pulmonary cases in the first and last quinquennia and the obvious deviation between these two periods. The estimate involves only one assumption. If it appears to the experts here today not to be justified, then the attempt fails. I have assumed that the ratio of non-pulmonary cases of human type tuberculosis to pulmonary cases remains constant over the whole period. If this is so, then the mortality rate from bovine type infection can be derived by simple subtraction. The result is shown in Table 3 . The small proportion of bovine pulmonary tuberculosis has been neglected.

This suggests that there was a highly significant increase in bovine tuberculosis up to the early years of this century with a subsequent fall to the 1851-55 proportion. I have not attempted to pursue the argument or to determine whether there was a higher point than that shown by this voL. 3, 1945] 
selection of dates. The rise would obviously correlate very closely with the increase, during the last half of the century, in the supply of milk, and the credit for the subsequent fall, proceeding alongside a still greater increase in milk consumption, will, I feel sure, be claimed both by those who have striven to improve the condition of dairy herds and by the advocates of pasteurization. What seems to me more important is that the fall in tuberculosis of human type has proceeded in a smooth, continuous and orderly fashion throughout the period.

TABLE 3

The Possible Incidence of Non-Pulmonary Bovine Tuberoulosis Mortality at Different Times Calculated from Standardized Rates per Million Population in Eagland and Wales given in Table 2

\begin{tabular}{c|c|c|c|c}
\hline & $\begin{array}{c}\text { Non-pulmonary } \\
\text { (human type) as } \\
18 \cdot 4 \text { per cont. of } \\
\text { respiratory }\end{array}$ & $\begin{array}{c}\text { Non-pulmonary } \\
\text { (bovine type) } \\
\text { by differonce }\end{array}$ & $\begin{array}{c}\text { Bovine as } \\
\text { por cent. of } \\
\text { total }\end{array}$ \\
\hline $1851-55$ & 2890 & 532 & 216 & $5 \cdot 9$ \\
$1901-05$ & 1209 & 222 & 309 & $17 \cdot 8$ \\
$1921-25$ & 816 & 150 & 100 & $9 \cdot 4$ \\
$1934-38$ & 532 & 98 & 38 & $5 \cdot 7$ \\
\hline
\end{tabular}

This in broad outline has been the experience of all western European countries. Tuberculosis has declined with increase in industrialization because, on the whole, industrialization has meant rise in the standard of living. The correlation is even closer with standard of living than with industrialization, for the improvement has not been uniformly distributed. Industrial depression has meant a lag in the depressed areas. In 1938 South Wales and Clydeside were the black spots. Rural areas have, on the whole, shown lower rates than urban areas but not always. A lower standard of living can annul the obvious advantages of country life. 'The same correlation with poverty is shown in the Registrar-General's (1938) occupational mortality data for males aged 20 to 65 years (Table 4).

\section{TABLE 4}

Mortality from Tumerculosis by Soctal Class. Rates as Percentage of Mean Ra'te for all Classes

\begin{tabular}{|c|c|c|c|c|}
\hline \multirow[b]{2}{*}{ Social class } & \multicolumn{2}{|c|}{ Respiratory } & \multicolumn{2}{|c|}{ Non-respiratory } \\
\hline & $192 \mathrm{I}-23$ & $1930-32$ & $1921-23$ & $1930-32$ \\
\hline 1. Business and professional & 49 & 61 & 70 & 43 \\
\hline 2. Trade, clerical, teaching, farmers & 81 & 70 & 95 & 86 \\
\hline 3. Skilled labour & 95 & 100 & 94 & 96 \\
\hline 4. Intermediate: farm labourers & 97 & 104 & 93 & 114 \\
\hline 5. Unskilled labour... & 137 & 125 & 103 & 97 \\
\hline
\end{tabular}

The position cannot be better summed up than by quoting Greenwood (1935): "It is not scientific or modern-minded or anything but foolish to try to believe that any other prophylaxis of this particular crowd-disease is so important as raising the economic level and increasing the commoda vitae of the crowd". 
What then of the important component or components of this standard of living? Some will immediately say housing, and no one would attempt to deny the importance of housing. The Chief Medical Officer of the Ministry of Health (1939) in his 1938 Report suggests that part of the credit should go to the 4 million new houses built between the end of the last war and 1938. But it has been shown by Orr and Wells (1944) that, in Scotland at least, the building of new houses since the last war has not even kept pace with the demand. It has been a replacement, an exchange, not a true expansion. The condition of slums, where tuberculosis was, and still is, at its worst, is believed by some not to have materially altered. Then there is the extension and improvement of tuberculosis services which, if often a form of salvage rather than prophylaxis, must have averted or postponed a certain number of deaths. Finally there is the considerable general improvement of diet always associated with rise in the standard of living of the poor and measurable in other ways than by tuberculosis mortality. Children have grown faster; other forms of disease and disability have been noticeably reduced. I think too that the ups and downs of the tuberculosis mortality rate with prosperity and depression throw the main emphasis on food. The housing shortage has been real and acute for a long time; people cannot move up or down in housing easily. And, it is an accepted economic law that with a rise in wages the poor improve first food, then clothing, and then housing if it can be improved and, with a fall in wages, the "extras" in food, on which health depends, are too often the first to go.

Let us look now at what happened in the last war. The position is illustrated by Table 5, which shows what happened in England and Wales as a whole and in Mental Hospitals (Cobbett, 1930).

TABLE 5

Increases in Tubercuxosis Dfaths in England and Wales and in MentaI Hospitals DURina the War 1914-18

\begin{tabular}{c|c|c|c|c}
\hline & \multicolumn{2}{|c|}{ England and Wales } & \multicolumn{2}{c}{ Asylums } \\
\cline { 2 - 4 } Year & Deaths & Excess over 1914 & Deaths & Excess over 1914 \\
\hline 1914 & 50,285 & - & 1871 & - \\
1915 & 54,282 & 3997 & 1955 & 84 \\
1916 & 53,855 & 3570 & 2327 & 456 \\
1917 & 55,931 & 5646 & $\mathbf{3 6 6 4}$ & 1793 \\
1918 & 58,071 & 7785 & 4685 & 2814 \\
& & 20,998 & & 5147 \\
& & 20,998 & \\
& & & & \\
& Population & $37,000,000$ & Population & 100,000 \\
\hline
\end{tabular}

Over the country as a whole there was an increase equivalent to less than half a year's mortality but in mental hospitals the increase was equivalent to nearly 3 year's' pre-war deaths. There was no very stringent blackout to inferfere seriously with the ventilation of houses; there was no blitz to destroy millions of houses, no evacuation to raise the bogey of spread of infection by infected evacuees to their hosts or of infection of evacuees by their hosts or from rural infected and unpasteurized milk supplies, vol. 3,1945$]$ 
but there was a real deterioration of diet. In the asylums the increase in tuberculosis was accompanied by an even greater increase in deaths from dysentery, and there can be little question of the association of outbreaks of dysentery with malnutrition, from the famous Millbank Penitentiary disaster in 1823 to the most up to date rat experiments. The Commission appointed to investigate the happenings in asylums decided that some deterioration in health might be due to the shortage of nurses and overcrowding, following the use of parts of the asylums for military hospitals, but that the main cause was "the unavoidable rcduction in the quantity and deterioration in quality of the food supplied to the patients" (Cobbett, 1930). Apart from the word "unavoidable", no student of nutrition is likely to quarrel with that verdict.

One point should be emphasized here: Cobbett (1930) in his analysis of the increased mortality between 1914 and 1918 says that, since the fall after the war was immediate and sustained, it is unlikely that new cases contributed to the increase. Most of the increase was due to old cases dying prematurely and he instances for comparison the effect of the siege of Paris in 1870-71, which lasted only for 5 months but gave a 35 per cent. increase for the 2 years 1870 and 1871 and a compensatory drop which lasted for 10 years.

The sequence of events is made more clear by what happened on the Continent and particularly in Denmark and Germany. Consider Denmark first. The tuberculosis mortality rate rose up to 1917 as long as large quantities of food were being exported, butter and eggs to this country, and meat, fish and vegetables in addition to butter and eggs, to Germany (Faber, 1938, 1939). In 1917, on account largely of the intensification of the submarine war, exports were greatly reduced or stopped, rationing introduced and subsidies arranged to keep prices down. This meant an immediate increase in home consumption of milk, butter, cggs and meat. The tuberculosis death rate responded at once and was falling in Denmark when it was at its maximum here and in other countries.

In Germany and also in Austria, the rise was much greater, and not only did the mortality rate increase but the clinical manifestations of the disease changed from the benign and chronic form with which we are familiar, and on which the concept of "racial immunity" is based, to the miliary and acute which we associate with primitive peoples when first in contact with the disease. Commentators, German (Kieffer, 1920) and American (Addams and Hamilton, 1919), say that "racial immunity", if it ever existed, was destroyed. From the official History of the Great War (Macpherson, 1924), there can be no doubt of the extreme deterioration of diet ( $c f$. also Starling, 1919). In many urban areas it approached. a "starvation diet". The end was staved off in 1917 by grain from Rumania, but the supplies of milk, meat and fats were extremely low. Hunger oedema was common in adults. The mortality rate in children was very high and altogether, according to a Nazi writer (Ziegelmayer, 1939), writing as late as 1939 , over 750,000 persons, children, women and old people, died of underfeeding because of the "hunger blockade". Shortage of protein and fat were held chiefly responsible and, therefore, the drive for protein and fat became the main urge in the self sufficiency programme for the present war. 
Is it possible to define any further this "malnutrition" as it affects tuberculosis? In Denmark, Faber $(1938,1939)$ has brought it down to shortage of animal foods. There was no noticeable food shortage in the sense of lack of calories and it was not shortage of fruit and vegetables, for these were scarcest in 1918 when the tuberculosis mortality rate was already falling. Faber (1939) instances as a parallel to events in Germany the history of tuberculosis in Greenland. In Eskimos, who have been in contact with tuberculosis for many years, the disease is highly benign and chronic so long as they maintain their natural diet of fish, meat and the contents of the caribou rumen but when, in the neighbourhood of trader settlements, imported carbohydrates form a substantial part of the diet, it becomes acute and fatal.

On the experimental side, a great deal of attention has been devoted to the possible implication of vitamin C, partly no doubt because of the early observations of Højer (1924) that the guineapig, which is highly susceptible anyway, is more susceptible when suffering from lack of vitamin C, and partly because of the effect of vitamin C on the formation of intercellular collagen. Højer's observations have been confirmed by some workers (Kleimenhagen, 1941; McConkey and Smith, 1933; Steinbach and Klein, 1941), not by others (Heise and Steenken, 1939). In one of the positive experiments (McConkey and Smith, 1933), 37 adult guineapigs on a diet partially deficient in vitamin $\mathrm{C}$ were fed daily with infected sputum. Of these 26 developed ulcerative intestinal tuberculosis. Of 35 controls, similarly exposed to infection but given adequate amounts of vitamin $\mathrm{C}$, only 2 showed intestinal ulceration. In another study (Steinbach and Klein, 1941), simultaneous injection of vitamin $\mathrm{C}$ and tuberculin into tuberculous guineapigs gave more fibrosis and less caseation than in controls given either tuberculin or ascorbic acid alone.

Numerous studies of blood ascorbic acid and of vitamin C saturation have been made on tuberculous patients. These agree in indicating some abnormality in the metabolism of vitamin $\mathrm{C}$ but give no indication of any specific effect on the course or issue of the disease. (See separate list of references: Clinical Tuberculosis and Vitamin C.)

Other workers have incriminated vitamin A deficiency. Some years ago it was shown that the rat, usually regarded as being "naturally immune" to tuberculosis, could be infected when fed on a poor diet (Grant, Suyenaga and Stegeman, 1927; Grant, Bowen and Stegeman, 1927). More recent work has shown that this is true of a diet devoid of vitamin A. One group of workers (Szule and Kolodziejska, 1933) was successful with 3 different strains of tubercle, another only with avian bacilli (Otero, Koppisch and Axtmayer, 1934). On the other hand, an experiment by Kon and Maddock (1938) in which skimmed milk from a cow with udder tuberculosis was given to a litter of 8 young pigs, of which 4 also received large doses of vitamin A, showed no effect of the vitamin, but the experiment appears to have terminated prematurely because of the death of one of the pigs not receiving vitamin A following an intradermal tuberculin test. MoKay (1940) was more successful with 2 groups each of 8 pigs, one on a good and one on a poor diet, differing chiefly in the supply of calcium and vitamin A, given a pure culture of tubercle in milk. There was evidence, from better localization of the disease, of greater resistance on the good diet.

vol. 3,1945$]$ 
Two more illustrations from involuntary experiments, on a lesser scale than the war experiments, with human diet. First are observations at a Norwegian army school for non-commissioned officers. The military authorities in Norway had been worried about the high tuberculosis morbidity and invaliding rates in some of their training schools from early in this century. One of the worst was the N.C.O. school in Trondhjem with an average of about 400 trainees. The men were billeted and fed in the town under very unsatisfactory conditions, two to a bed in small rooms. Pressure from the medical side finally resulted in the building of new, very well equipped barracks, with a modern ventilating system, central heating, baths, individual wash basins, hot and cold water and a woman for each floor to clean. The school moved into the new barracks in 1911, but instead of falling, the morbidity rate rose, in the 4 year period 1921-24 to nearly 50 per cent. above the 1905-08 level. The peak was reached in 1921 when 13 out of 40 entrants developed tuberculosis and had to be sent home. The pupils were all highly selected young men, entering as physically fit and of better than average physique. Candidates from homes where there was a known case of tuberculosis were, at that time, not admitted, and yet the morbidity rate was far above that of their own age class in general. After a few months in the school they became obviously physically unfit, unable to go through the prescribed course of training, subjectively tired, depressed and complaining of pains in their legs. Bronchitis was very common and there were epidemics of enteritis.

The diet during the period from 1911 to 1925 was provided by the army catering department. It is described as resembling the outfit for an Arrtic expedition, "an arsenal of tins", smoked, salted and dried meat and fish, condensed, partly skimmed milk, dried peas, prunes, cereals and so on. The cooking facilities were inadequate and the potatoes, put into boiling water, took 3 hours to come to the boil.

The diet was reformed, as far as was possible within the limits of army regulations, in 1925. Condensed milk was replaced by fresh milk, unboiled and unpasteurized, and cream. Vitaminized margarine, cod liver oil and wholemeal bread were introduced and all the fresh vegetables and fruit that could be got were provided. Raw carrots and turnips were served as a savoury.

The tuberculosis rate and all the other sickness rates responded immediately. The tuberculosis rate fell at once to that of the best schools and up to 1935, the date of the last report, there had been no subsequent recurrence (Øverland, 1933, 1935).

Second, Burns (1934) from a survey in Co. Durham considers that nonpulmonary tuberculosis occurs in children who receive little milk, not in those who get a lot of milk. In this connexion let me remind you that up to the beginning of this war at least, the poor not only got less milk than the rich, but used scarcely any fresh or pasteurized liquid milk at all. For instance, the poorest 10 per cent., among whom the tuberculosis death rate is highest, used only 1 pint per head per week of liquid milk and $5 \cdot 4 \mathrm{oz}$. condensed milk, equivalent of 0.7 pint liquid. The richest 30 per cent. among whom tuberculosis mortality is least, used $5 \cdot 7$ pints per head weekly and $0.7 \mathrm{oz}$. condensed milk, equal to only about 0.1 of a pint liquid. 
Yet there are those among us who are concerned lest the present war time increase in tuberculosis should be due to the drink-more-milk campaign. We shall hear in the afternoon what the experts have to say about that.

In the meantime, let us take a preliminary glance at the present war. The report of the Committee on Tuberculosis in War-Time (1942) reviewed the position in the present war up to the end of 1941. In summary it was as shown in Table 6 .

TABLE 6

Percentage Increase in Tuberculosis Mortajity 1938-39 to 1941



The outstanding feature is the great increase in meningitis, and this the Committee interprets as meaning that the disease had "assumed a more acute and fatal form". Just what the Committee had in mind there, we do not know, but we do know that such a change as this does not necessarily mean a rise in virulence of the infecting organism; it may equally well mean a fall in the resistance of the population at risk. From the nutritional point of view there is evidence to support the latter interpretation. The recent report of the Special Joint Committee Set up by the Combined Food Board (1944) states that there was a definite deterioration of the national diet, which reached its lowest level in the first half of 1941. Then, it is suggested, there was a net food shortage with the biggest deficits in animal protein and fat. Following the introduction of Lend Lease and the commencement of arrivals in this country of dried milk, dried eggs and canned meats from America, and with the maturing of the home production programme, there was a steady improvement in the food situation. At present, the national diet is judged to be adequate in energy value and in respect of most individual constituents, although of course, in spite of rationing, it is still not evenly distributed. It seems certain that the diet of the poorest has improved and possible that that of the middle and upper classes has deteriorated somewhat in quality as well as being considerably reduced in quantity where, on the whole, such a reduction should be well tolerated.

We do not know what has happened to the tuberculosis mortality rate since 1941. I hope we shall be told something about it today. Perhaps when we know all the facts about both we shall have a basis for a more precise definition of the relationship of diet to resistance to tuberculosis.

voL. 3,1945$]$ 


\section{REFERENCES}

Addams, J. and Hamilton, A. (1919). Brit. J. Child. Dis. 16, 129.

Burns, C. M. (1934). J. State Med. 42, 157.

Chief Medical Officer, Ministry of Health (1939). Rep. med. Offr Minist. Hlth, Lond., 1938.

Cobbett, L. (1930). J. Hyg., Camb., 30, 79.

Committee on Tuberculosis in War-Time (1942). Spec. Rep. Ser. med. Res. Coun., Lond., no. 246.

Faber, K. (1938). Tuberculosen i Danmask. 3. Tuderculose og Emaering. Copenhagen: Gyldendalske Boghandel.

Faber, K. (1939). Ugeskr. Loeg. 101, 1148.

Grant, A. H., Bowen, J. A. and Stegeman, D. E. (1927). Amer. Rev. Tuberc. 16, 642 .

Grant, A. H., Suyenaga, B. and Stegeman, D. E. (1927). Amer. Rev. Tuberc. 16, 628.

Greenwood, M. (1935). Epidemics and Crowd Diseases. London: Williams and Norgate, Ltd.

Heise, F. H. and Steenken, W. (Jr.) (1939). Amer. Rev. Tuberc. 39, 794.

Højer, J. A. (1924). Acta paediatr., Stockh., Suppl. 3.

Kieffer, O. (1920). Z. Tuberk. 32, 65.

Kleimenhagen, P. (1941). Z. Vitaminforsch. 11, 209.

Kon, S. K. and Maddock, C. (1938). Vet. Rec. 50, 1693.

MeConkey, M. and Smith, D. T. (1933). J. exp. Med. 58, 503.

McKay, W. M. (1940). J. comp. Path. 53, 112.

Macpherson, W. G. (1924). History of the Great War. Medical Services and Diseases in the Great War. London: H.M.S.O.

Orr, J. B. and Wells, F. (1944). Housing and Health. London and Letchworth: Dent and Sons.

Otero, P. M., Koppisch, E. and Axtmayer, J. H. (1934). Puerto Rico J. publ. Hlth, 9, 314 .

Øverland, A. (1933). Nord. med. Tidskr. 5, 70.

Øverland, A. (1935). Tidsskr. norske Loegeforen. no. 13.

Registrar-General (1938). England and Wales Decennial Supplement. Pt. 2a, Occupational Mortality, 1931.

Special Joint Committee Set up by the Combined Food Board (1944). Food Consumption Levels in the United States, Canada and the United Kingdom. London: H.M.S.O.

Starling, E. H. (1919). Report on Food Conditions in Germany. London: H.M.S.O.

Steinbach, M. M. and Klein, S. J. (1941). Amer. Rev. Tuberc. 43, 403.

Szule, G, and Kolodziejska, S. (1933). C.R. Soc. Biol. Paris, 112, 591; 593; 595.

Wilson, G. S. (1942). The Pasteurization of Milk. London: Edward Arnold and Co.

Ziegelmayer, W. (1939). Rohstoff-Fragen der deutschen Volksernährung. Dresden and Leipzig: T. Steinkopff.

\section{Clinical Tuberculosis and Vitamin $\mathrm{C}$}

Armand-Delille, P. and Urbain, G. (1938). C.R. Soc. Biol. Paris, 127, 522.

Bumbalo, T. S. and Jetter, W. W. (1938). J. Pediat. 13, 334.

Dagulf, H. (1938). Nord. med. Tidskr. 16, 1315.

Erwin, G. S., Wright, R. and Doherty, C. J. (1940). Brit. med. J. i, 688 ,

Getz, H. R. and Koerner, T. A. (1941). Amer. J. med. Sci. 202, 831.

Groth-Petersen, B. and Groth-Petersen, E. (1939). Nord. Med. 3, 2141.

Jetter, W. W. and Bumbalo, T. S. (1938). Amer. J. med. Sci. 195, 362.

Kaplan, A. and Zonnis, M. E. (1940). Amer. Rev. Tuberc. 42, 667.

Martin, G. J. and Heise, F. H. (1937). Amer. J. digest. Dis. Nutrit. 4, 368.

Munro, W. T., Westerwater, J. O. and Ross, D. C. (1942). Edinb. med. J. 49, 508. Pilz, J. (1938), Med. Klinik, 34, 227.

Sweany, H. C., Clancy, C. L., Radford, M. H. and Hunter, V. (1941). J. Amer. med. Ass. 116, 469.

Warns, E. H. J. (1938). Ned. Tijdschr. Geneesk. 82, 4426. 


\title{
Tuberculosis in Scotland: Present Position
}

\author{
Dr. J. S. Westwater (Department of Health for Scotland, St. Andrew's \\ House, Edinburgh)
}

While most indices of the health of the community have displayed remarkable improvements under war time conditions, tuberculosis has shown a serious deterioration. Trends of tuberculosis are judged by the Registrar General's record of deaths and the notifications of cases made to Medical Officers of Health by doctors and collated annually by the Department of Health. Deaths are on the whole regarded as a more reliable index than notifications.

In man tuberculosis is a disease which kills quickly, as in the meningeal and miliary forms, or slowly, as in the chronic pulmonary form. It may incapacitate for months or years: it can cripple, as in the bone and joint affections. As a "killer", tuberculosis is most dangerous to children under 5 , to young women and to men in the working age periods of life.

For statistical purposes, the disease is recorded in two categories: (1) pulmonary tuberculosis, which represents in the main the adult form of the disease, and the variety most commonly due to the human tubercle bacillus; (2) non-pulmonary tuberculosis, which includes several varieties of the disease, the acute fatal forms such as meningeal and miliary or disseminated tuberculosis, the bone and joint affections, the abdominal, the glandular, and special forms such as lupus. Most of the childhood cases and deaths are to be found in the non-pulmonary group which embraces forms in which bovine infection plays a significant role, with the chief example abdominal tuberculosis, which is almost invariably of bovine origin.

In considering war time changés, abdominal tuberculosis may be used as a measure of bovine infection, and pulmonary tuberculosis, of human infection. In the acute forms, meningeal and miliary, the part played by human and bovine infection is variable, depending largely on domicile; human infection is to be expected in urban cases while there is more chance of bovine infection being the cause in rural cases.

\section{Pre-War Trends}

Mortality records in Scotland date from the middle of last century and show (Figure 1) that the death rate from tuberculosis rose to a peak about 1870 with 382 deaths per 100,000 , following which there has been a decline, not entirely even, in the rate of fall. In 1938 the death rate of 69 was the lowest on record and was only 18 per cent. of the 1870 peak figure of 382 . This remarkable decline began before comprehensive schemes for the prevention and treatment of the disease were in being and in large measure may be ascribed to rising living standards. The important factors in living conditions are considered to be nutrition, housing and industrialization.

Compared with England and Wales, Scotland began the century with a higher mortality, the quinquennial figures being 218 and 174 , respectively, per 100,000, but from 1910 onward, Scotland showed a greater rate of decline, apparently not being so adversely affected by the war conditions of 1914-18. The respective rates for 1931-35 were 80 for Scotland and 78 for England and Wales. Latterly, prior to the outbreak of this war, voL. 3,1945 ] 
mortality in Scotland was declining at a slower rate, the English death rate falling to 60 in 1938 compared with 69 for Scotland. The slowing in Scotland was due to the higher death rate from pulmonary tuberculosis, which did not fall so rapidly in Scotland as in England and Wales. Thus, although Scotland had gained on the neighbour kingdom in the earlier years of this century, parity was not achieved at any time and indeed some ground was being lost in the immediate pre-war period from 1935 to 1938 . Records of notifications, which date from 1912, show similar trends.



Figure I. Tuberculosis All Forms. Qurnquennial Death Rates PER 100,000 Population.

Scotland's less favourable pre-war position may be ascribed to major factors such as overcrowding, proportionately more industrialization and the ill effects of trade depression. The highest death rates occurred in the industrial towns of the Clyde basin. There were also special factors operative in some areas such as the Highlands and Islands. 
Overcrowding in Scotland before the war was 6 times as bad as it was in England. It is interesting to note that the periods when the mortality rates in Scotland were falling most quickly and gaining towards the English rate followed on peak periods of house building in Scotland around 1875-80 and 1900-05 (Figure 2). The retardation in the decline of mortality in the immediate pre-war years may be associated with the fact that in Scotland the building of houses was failing to keep pace with housing progress in England (Scottish'Housing Advisory Committee, 1944).



Figure 2. Houses Built in Scotland and in England and Wales BETWEen ThE Two Great Wars. The graph shows that on a proportionate population basis the output of new houses in England and Wales was consistently higher than in Scotland. This was mainly due to the fact that 30 houses were built by private enterprise in Fingland and Wales for each house so erected in Scotlancl.

Reproduced from Report by the Scottish Housing Advisory Committee (1944) by courtesy of H.M. Stationery Office.

Scotland therefore was at a disadvantage at the start of this war and it is not surprising that the adverse trends in the disease since have been more marked in Scotland.

voL. 3, 1945] 


\section{War Time Changes}

All susceptible groups have suffered during the war, children, young women and adult males. As tuberculosis was declining in the pre-war period, 1938, the last complete year of peace time conditions, may be taken as a base line on which to estimate changes that have taken place since. It has to be remembered that such estimates are an understatement of the deterioration that has occurred as they do not allow for the continuance of the falling trend of the disease that might have been expected without the advent of war.

In 1938, 3432 persons died from the disease, representing 5 per cent. of all deaths; 7565 cases were notified and at the end of the year 29,000 persons were known to be suffering from the disease.

\section{Gross Changes}

Gross changes are set out in Table 1.

TABLE 1

Tuberculosis in Scotland: Deaths and Notifications in 1938-43

\begin{tabular}{|c|c|c|c|c|c|c|}
\hline \multirow[b]{3}{*}{ Year } & \multicolumn{6}{|c|}{ Type of infection } \\
\hline & \multicolumn{2}{|c|}{ Pulmonary } & \multicolumn{2}{|c|}{ Non-pulmonary } & \multicolumn{2}{|c|}{ All forms } \\
\hline & Deaths & Notifications & Deaths & Notifications & Deaths & Notifications \\
\hline 1938 & 2580 & 4793 & 851 & 2772 & 3431 & 7565 \\
\hline 1939 & 2717 & 4657 & 809 & 2440 & 3526 & 7097 \\
\hline 1940 & 3037 & 5212 & 966 & 2510 & 4003 & 7722 \\
\hline 1941 & 3117 & 5739 & 1058 & 2555 & 4175 & 8294 \\
\hline 1942 & 3041 & 6224 & 954 & 2824 & 3995 & 9048 \\
\hline 1943 & 2976 & 7215 & 983 & 2873 & 3959 & 10088 \\
\hline
\end{tabular}

Pulmonary tuberculosis has increased in respect of both deaths and notifications. The greatest increase in pulmonary deaths occurred in 1941. Notifications have risen steadily with each year of war and in 1943 were 54 per cent. in excess of 1938. Non-pulmonary deaths tend to follow the pulmonary deaths. It may be said that pulmonary tuberculosis in terms of deaths has slipped back to the 1930 level; in terms of notifications, back to the 1925 level. The increase in notifications may to some extent be discounted by the improved ascertainment associated with enlistment medical boards and the introduction of mass radiography in the Services. Stocks (1944) has estimated that for England probably about half the war time excess in notifications may be due to such factors, the increase in respect of time sequence and age groups following closely the call up for military service in 1941-42.

In Scotland the increase in notifications of pulmonary tuberculosis does not bear this close relationship to war service, increases being distributed over most age groups and suggesting that the greater excess in Scotland compared with England is due to spread of the disease in the civil population.

The respective percentage war time changes in deaths and notifications are shown in Figure 3 and Table 2. Compared with England and Wales, Scotland has suffered more from the adverse war time trends of the disease, females especially showing a greater increase in both the pulmonary and meningeal forms of the disease. 


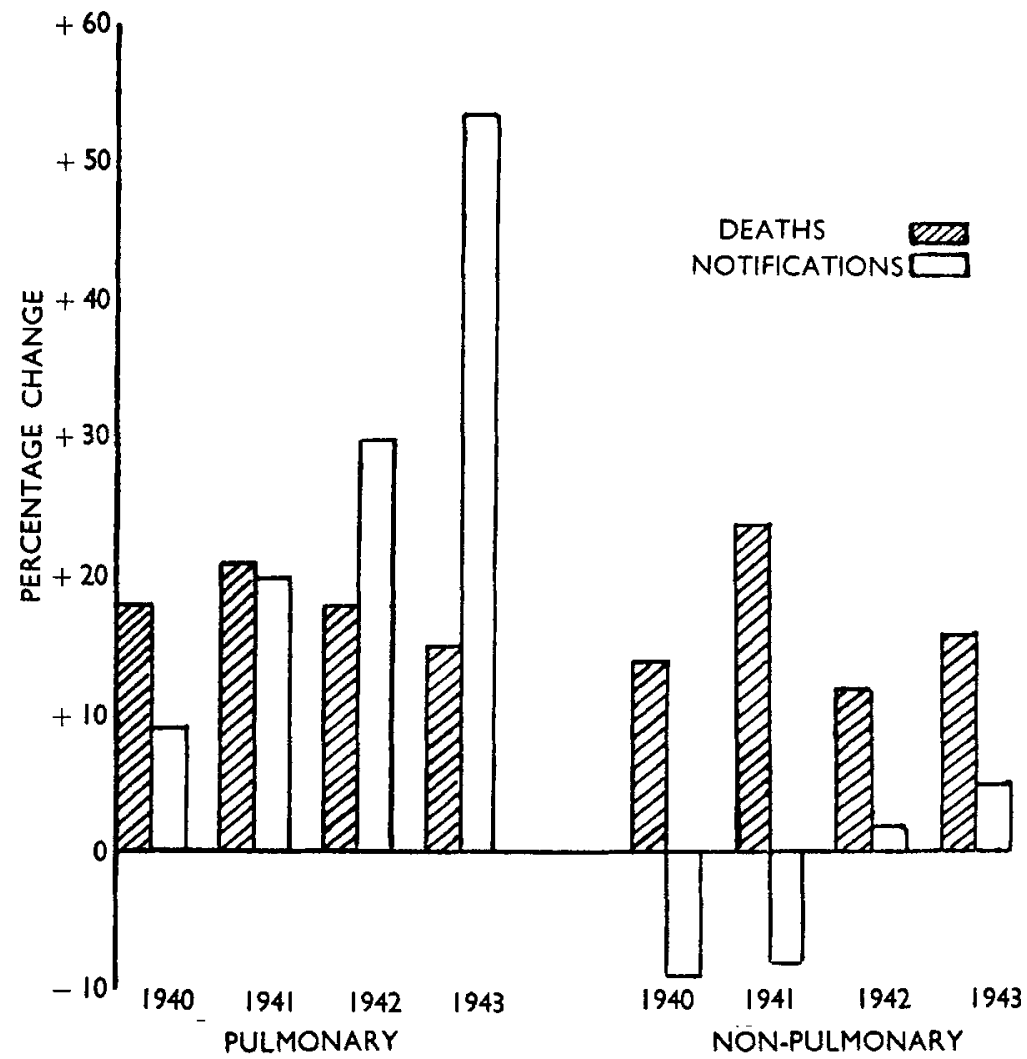

Figure 3. 'Tuberoulosis in Scotland. Increase or Decrease of Deaths AND Notifications iN 1940 to 1943 OOMPARED WITH 1938.

TABLE 2

Tuberculosis in Scotrand: Percentage Changres in Deaths and Notifications iN WAR Time

\begin{tabular}{|c|c|c|c|c|c|c|c|c|}
\hline \multirow[b]{3}{*}{ Type of change } & \multicolumn{8}{|c|}{ Type of infection } \\
\hline & \multicolumn{4}{|c|}{ Pulmonary } & \multicolumn{4}{|c|}{ Non-pulmonary } \\
\hline & 1940 & 1941 & 1942 & 1943 & 1940 & 1941 & 1942 & 1943 \\
\hline $\left.\begin{array}{c}\text { Percentage increase } \\
\text { or decrease com- } \\
\text { pared with } 1938\end{array}\right\} \begin{array}{c}\text { Deaths } \\
\text { Notifica- } \\
\text { tions }\end{array}$ & $\begin{array}{r}+18 \\
+9\end{array}$ & $\begin{array}{l}+21 \\
+20\end{array}$ & $\begin{array}{l}+18 \\
+30\end{array}$ & $\begin{array}{l}+15 \\
+54\end{array}$ & $\begin{array}{r}+14 \\
-9\end{array}$ & $\begin{array}{r}+24 \\
-8\end{array}$ & $\begin{array}{r}+12 \\
+2\end{array}$ & $\begin{array}{r}+16 \\
+5\end{array}$ \\
\hline
\end{tabular}

Deaths in Age and Sex Groups

Comparing the sexes, the war time increases in mortality are greater in females from both pulmonary and non-pulmonary forms of the disease. The difference is not great for pulmonary tuberculosis but is more evident in the non-pulmonary forms. The increase in non-pulmonary deaths is due to an excess in the acute forms, meningeal and disseminated.

voL. 3, 1945] 
Examining these features in relation to age groups, it is found that female deaths from pulmonary tuberculosis in 1941 showed an excess in nearly all age groups, with a maximum at ages 15 to 35 . Non-pulmonary deaths in women showed a marked excess at ages 15 to 25 .

Males in 1941 showed an increase at all ages, highest at 35 to 45 . In 1942 and 1943 excess male deaths have been mainly at ages over 35 . In females, changes in 1942-43 have been similar to those in 1941 but of less degree. Both sexes under 15 years of age showed increases in each year pointing to human infection as being mainly operative in the childhood war time deaths.

Analysing non-pulmonary deaths in relation to age and sex groups the significant age periods are found to be under 5 , and 15 to 25 . The greatest increases are in the age period 15 to 25 , both sexes being affected.

It is of interest to note that in 1943 the young adult male deaths from pulmonary tuberculosis at ages 15 to 35 had fallen back to the 1938 level, but not the non-pulmonary deaths. There were still excesses of pulmonary deaths in the older males, in the young adult females and in children. Deaths from non-pulmonary tuberculosis in 1943 showed females still more affected than males in the age period 15 to 35 , and contributing the greatest proportional excess, 40 to 44 per cent. over 1938.

\section{Deaths Classified by Site of Infection}

Table 3 shows the results of this classification.

TABLE 3

Tuberculosis in Scotland: Deaths Classified by Site of Infection, 1938-43

\begin{tabular}{|c|c|c|c|c|c|c|c|c|c|c|c|c|}
\hline \multirow[b]{2}{*}{ Site of infection } & \multicolumn{6}{|c|}{ Number of deaths } & \multicolumn{6}{|c|}{$\begin{array}{l}\text { Number of deaths ex- } \\
\text { pressed as percentage of } \\
\text { those occurring in } 1938\end{array}$} \\
\hline & 1938 & 1939 & 1940 & 1941 & 1942 & 1943 & 1938 & 1939 & 1940 & 1941 & 1942 & 1943 \\
\hline All forms & 3431 & 3526 & 4003 & 4175 & 3995 & 3959 & 100 & 103 & 117 & 122 & 116 & 115 \\
\hline Pulmonary & $|2580|$ & 2717 & 3037 & 3117 & $|3041|$ & {$[2976]$} & 100 & 105 & 5 118 & 121 & 118 & 115 \\
\hline $\begin{array}{l}\text { Non-pulmonary } \\
\text { Central nervous }\end{array}$ & 390 & 377 & 485 & 567 & 514 & 545 & 100 & 97 & $7 \mid$ & 145 & 132 & 139 \\
\hline Intestines and peri- & 135 & 118 & & & & 100 & 100 & 87 & 89 & & 100 & 100 \\
\hline $\begin{array}{l}\text { Bones and joints, } \\
\text { including verte- }\end{array}$ & & & & & & & & & & & & \\
\hline bral column & 94 & 94 & 92 & 72 & 86 & 82 & 100 & 100 & 98 & 77 & 92 & 87 \\
\hline Disseminated & 169 & 160 & 234 & 231 & 157 & 193 & 100 & 95 & $5 \mid 138$ & \begin{tabular}{l|l|}
3 & 137
\end{tabular} & 93 & $3 \mid 114$ \\
\hline Other sites & 63 & 60 & - 44 & 54 & 59 & 54 & 100 & 95 & 70 & 86 & 94 & 86 \\
\hline Total non-pulmonary & 851 & 809 & 966 & 1058 & 954 & 983 & 100 & 95 & $5 \quad 114$ & $4 \quad 124$ & 112 & 116 \\
\hline
\end{tabular}

As already mentioned non-pulmonary deaths are a composite group including both acute forms of the human type and also forms, such as abdominal tuberculosis, almost entirely due to bovine infection. Considering non-pulmonary deaths classified according to site, the excess mortality in the war years has been due to increases in the acute forms, 
namely, meningeal and disseminated tuberculosis. Given adverse conditions commencing at the outbreak of war one would expect that, apart from deaths of existing cases of chronic disease, an initial effect on mortality figures would be to increase deaths from the acute forms of the disease and that, in subsequent years, the corresponding quota of deaths from the chronic variety, such as pulmonary tuberculosis, would fall. On this argument a decrease in deaths from the acute forms might be the first signal of improvement. If this be so, it is to be noted that in 1943 meningeal and disseminated tuberculosis was still in excess of the 1938 level.

If abdominal tuberculosis be accepted as an index of bovine infection, it is of interest that deaths from this form of the disease have, on the whole, tended to fall slightly, although in 1941 and 1942 the number of deaths was almost the same as in 1938. It has been considered that the evacuation schemes, increasing the risk to urban children of contracting bovine infection from raw milk consumed in rural areas, may have affected unfavourably the trend of mortality in children.

\section{Changes in Notification}

With regard to the notifications the striking feature is the progressive rise in pulmonary tuberculosis, which may be taken as presumptive evidence that human rather than bovine infection has been the important factor. As in mortality, females show a greater increase than males and the age group in females showing the greatest increase has covered the range 15 to 45 , with some prominence in the 15 to 25 group. The changes in male notifications are similar and both sexes under 15 show a progressive rise.

Notifications of non-pulmonary tuberculosis, which on the whole have not shown much change, do not on analysis by age and sex groups show any particular trend.

\section{Geographical Changes}

Pre-war the death rates from tuberculosis were higher in the cities and large burghs than in the county areas, apart from the special case of the Highlands and Islands. In the war years, the increase in tuberculosis mortality has been of a higher order in the towns than the counties. In 1941, the increase was 28 per cent. in the towns and 19 per cent. in the counties.

\section{Seasonal Effect}

A factor that may have contributed to the increase in deaths from pulmonary tuberculosis in 1940 and 1941 was the severe weather in the early months of these two years. Deaths in the first quarter of 1940 and 1941 showed a seasonal excess, more marked than usual, and corresponding with a rise in other respiratory deaths and mortality generally.

\section{Conclusions}

The adverse factors which may have been operative to produce the war time increase in tuberculosis mortality were reviewed by a committee of the Medical Research Council (Committee on Tuberculosis in WarTime, 1942). No one factor could be singled out, but attention was vor. 3, 1945] 
drawn to the evacuation of tuberculosis hospitals and sanatoria, the black out conditions restricting ventilation, evacuation, increasing overcrowding, increased industrialization adding to the number of susceptible age groups in industry and acting qualitatively through the longer hours of work and strain of travel, and the curtailment of rest and recreation by extraneous duties such as Civil Defence.

Nutrition as such has not been directly implicated. The results of dietary surveys and the favourable changes in other health indices have not suggested that nutrition is at fault. In fact it may be better than before the war because of the even distribution over the whole population of essential foods by the rationing scheme and the differential shift to priority groups of certain foods, such as milk, which is important in relation to tuberculosis both as a first class food and, unfortunately, as a potential source of bovine infection.

\section{REFERENCES}

Committee on Tuberculosis in War-Time (1942). Spec. Rep. Ser. med. Res. Coun., Lond., no. 246.

Scottish Housing Advisory Committee (1944). Planning our New Homes. Edinburgh: H.M.S.O.

Stocks, P. (1944). Practitioner, 153, 1.

\section{The Clinical Position with Particular Reference to Diet}

\section{Dr. R. Y. Keers (Tor-na-Dee Sanatorium, Aberdeenshire)}

The relationship between the nutritional state of the patient and the activity of the tubercle bacillus has been recognized since the days of Aretaeus, whose classic description of the phthisical case in the second century stresses the muscular wasting and the general appearance of emaciation. Today we still list lassitude and loss of weight among the early symptoms of tuberculosis, and furthermore we recognize malnutrition as one of the causes leading to a breakdown in resistance and to the appearance of clinical disease. It is clear, therefore, that diet and tuberculosis have a direct bearing one upon the other but, at the same time, it must be emphasized that the cause of tuberculosis is infection by the tubercle bacillus and that malnutrition is only a contributory factor. That it is an important factor is made amply clear by the literature from the last war, particularly the work of Faber $(1938,1 ; 1939)$, which has already been mentioned by one of the previous speakers. If further confirmation is required, it is forthcoming in the facts and figures now emanating from areas of enemy occupied Europe. In France, in the Seine department there has been a rise in the number of new cases detected, from 141 per 100,000 in 1938 to 176 in 1942 (Vignal, 1943-44). The disease is changing in character and now tending to assume a bronchopneumonic form, with rapid and fatal extension, often only 3 months elapsing between the onset of symptoms and death. This form is seen in patients who have wasted rapidly without showing any signs in a systematic X-ray examination (Vignal, 1943-44). No figures are available for Greece, owing to the impossibility of attempting to keep records in 
present conditions, but we have the statement of the president of the Greek Red Cross that tuberculosis has spread tremendously.

In Britain, where famine conditions do not exist and havo not existed for years, we have no such overwhelming evidence as this. We know that malnutrition is a factor in lowering resistance; our clinicians can point to numerous instances in the past where it has been the prime factor but, with regard to the rise in incidence which we have witnessed during the present war, we cannot produce evidence pointing unequivocally to malnutrition as being the sole, or even the most important, precipitating cause. A review of the part played by diet in the treatment of the tuberculous case may allow us to see the question in truer perspective.

In discussing the clinical aspect of the relationship between diet and tuberculosis, and I am regarding the term "clinical" strictly in the sense suggested by its derivation, the study of the disease at the bedside, we use loss of weight as our yardstick, this being, as a rule, a reasonably accurate method of assessing the degree of malnutrition. It is not, of course, claimed that loss of weight invariably constitutes the sole evidence of dietary deficiency. The loss of weight which is associated with activity of the tubercle bacillus is a fairly constant clinical manifestation and usually appears early in the course of the disease. In the initial stages it is slight, but, as the disease process evolves, tissue wasting slowly but steadily increases. In the more advanced case it is marked and may at times approach emaciation.

This loss of weight is due mainly to the toxaemia engendered by the metabolism of the tubercle bacillus, a fact demonstrated by the evidence of emaciation which accompanies experimental tuberculosis in animals. It may, of course, be increased at a later stage by the digestive disturbances which tuberculosis brings in its train or by the development of tuberculous foei in the alimentary tract itself, but even with satisfactory gastrointestinal function it is still constantly encountered.

With loss in weight as such a frequent clinical finding, it is natural that improvement of the nutrition of the patient should occupy a prominent place in any therapeutic regime. For a time, indeed, diet was regarded as all important in the treatment of the disease, and Walther's process of superalimentation, in which his patients were literally crammed with food, usually without regard for their ability to digest it, was widely adopted in the early sanatoria. This teaching has nowadays been modified out of all recognition, and, although the adequate provision of suitable food is still considered of very great importance, it is realized that the treatment of pulmonary tuberculosis is far from being entirely a matter of diet, or even of diet combined with fresh air.

The basic cause of the loss of weight is toxaemia; and it follows that, besides supplying the nutriment to make good the loss of weight, measures designed to reduce and eventually eliminate the causal toxaemia must also be adopted. The most important of these measures is rest and, indeed, the application of rest is the fundamental principle of all therapeutic efforts in pulmonary tuberculosis. By resting the patient, and by this is meant bed rest, absolute bed rest if necessary, the respiratory effort is reduced to a minimum and the resultant slackening off in lung movements produces, among other beneficial effects, a diminution in vor. 3,1945$]$ 
the absorption of toxic products into the circulation. The results of rest become evident clinically in an increased feeling of well being, a progressive decrease in temperature and an improvement in appetite, which is soon followed by a gradual and usually steady gain in weight. This gain in weight may be interpreted as a favourable sign that the patient is responding to treatment, but it must be emphasized that rest is a more important factor in its initiation than any special dietetic measure.

The dietetic treatment of tuberculosis has, since the days of Walther, been placed on a much more rational footing, and there is now general agreement that 3 well balanced meals daily, given at regular times, constitute its basis. To fulfil its function the food should be pleasant, varied and satisfying. It should be that which the patient likes, or to which he is accustomed, and should be a little more in quantity than that required by the average healthy person of similar physique. The times of the meals should coincide as far as possible with those customary to the class of patient under treatment. As a rule, there is no necessity to give extra nourishment between meals, a point on which the patient and his relatives often do not see eye to eye with the medical adviser. These additional snacks merely interfere with appetite at regular mealtimes and place an additional and unnecessary burden on the gastrointestinal tract. If, however, the patient is much below weight in the early stages of his treatment, milk or egg flip may be permitted in midmorning for a time, provided the intake of food at the midday meal is not thereby reduced.

As far as the composition of the daily menu is concerned, provision must be made for an adequate supply of protein, carbohydrates, fats, minerals and vitamins, and also, for those patients without gastrointestinal disturbance, for roughage. The calorie intake should be round about 3000 daily, but no exact formula can be laid down, and the safest rule is to ensure that the patient gets rather more food than would be required by his healthy prototype. The exact sources from which the calories are to be derived is still a matter of some doubt.

Most authorities are agreed on the necessity for a moderate relative and absolute increase in the protein constituents, because of the part which protein plays in the repair and renewal of exhausted tissues, and because tissue destruction and tissue wasting are clinically evident in tuberculous disease. The best source of protein is food of animal origin, and in normal circumstances of peace this protein need was met by a good helping of meat and of fish daily, together with an egg and a pint of milk. Rationing interfered with menu planning, the protein element being the chief sufferer, and the only concession which was considered necessary for the tuberculous patient was the provision of 2 pints of milk daily. Results have justified this official view: the extra milk, a more judicious use of the cheese ration and of unrationed commodities which could be obtained in limited quantity, combined with an increase in the intake of vegetable protein, have enabled the patient to carry on with his nutrition unimpaired.

Carbohydrates are easily assimilated and digested and, properly selected, should form an important part of the dietary. They have fulfilled their role as "protein sparers" during rationing, and there has been an all round rise in the consumption of bread and potatoes to compensate for the 
reduction in the amount of protein available. Whether carbohydrates have any specific part to play in the treatment of tuberculosis is still undecided. Day (1942) has reported results showing that patients receiving excess carbohydrate in the form of sugar gained weight more rapidly than those receiving the ordinary sanatorium diet, while there was also a corresponding improvement in their sedimentation indices. From this he concluded that additional carbohydrate was the most satisfactory supplement in the diet of the tuberculous patient. Gain in weight, however, is not necessarily evidence of healing of the tuberculous lesion, and further investigation along these lines would appear to be necessary before finally ascribing special curative properties to the carbohydrate group. It may be added that there is other evidence to suggest that excess of carbohydrates is associated with a more exudative and rapidly spreading type of disease. The general view at present is that the carbohydrates play the same part in the diet of the tuberculous as they do in the diet of the general population and that they should be prescribed accordingly.

Extra fat has long been considered an essential in the treatment of tuberculosis, and has often in the past been pushed with unnecessary vigour. The capacity to digest and absorb fat varies with the individual patient, and there are many in whom an excess of fatty foods leads simply to nausea and gastro-intestinal disturbance. An attempt to clear up the question of additional fat in the diet was made at Tor-na-Dee during 1942 and 1943 (Keers, 1943) when, with the help of the Medical Research Council, a series of experiments was carried out in which fat, over and above that provided in the normal diet, was given in the form of vitaminized margarine. In the initial stages the quantity prescribed was calculated to provide 1000 Calories daily, but this was quickly found to be far in excess of that with which even the most cast iron digestive system could conveniently deal. Accordingly, the quantity was halved, but even this proved too much for a proportion of the participants, although a reasonable number struggled through to the end. Our conclusions from the experiment were summed up as follows:

(1) The nature of the experiment resulted in the participants being a more or less self selected group. In other words, only those with a thoroughly sound digestive system and a high fat tolerance could compete.

(2) These patients did show a more rapid gain in weight during the first 4 months than the controls, but at the end of 9 months there was little to choose between the groups.

(3) There was not sufficient evidence to suggest that the more rapid initial gain in weight played any important part in their recovery.

(4) The difficulties experienced in getting patients to consume and digest the fat appeared a strong argument in favour of supplying their extra calorie requirements in some more readily assimilable form.

The lesson to be learnt from this work is that there is nothing to be gained, and indeed something to be lost, by any attempt to force the fat intake beyond that which the patient can assimilate completely. An voL. 3,1945$]$ 
adequate supply of fat is necessary, but this need can be met by the butter and margarine ration, the fat of meat and bacon, and fat fish, together with cheese and milk. For those to whom the eating of meat and bacon fat is a difficulty, cod liver oil may be administered, but normally, and contrary to popular belief, there is little need for it from the point of view of either its fat or vitamin content, if a good mixed diet is provided and consumed. It has become almost a tradition to prescribe cod liver oil, but it should be reserved for those whose digestion is sound, and excessive dosage should be avoided. One teaspoonful 3 or 4 times a day is sufficient.

Provided that a full balanced diet is being given and ingested, the vitamins should look after themselves. Attention has, however, been drawn to a state of vitamin $\mathrm{C}$ unsaturation existing in pulmonary tuberculosis (Heise and Martin, 1936; Abbasy, Harris and Ellman, 1937; Hurford, 1938), and investigations have been carried out to determine the results of saturating tuberculous patients with vitamin $\mathbf{C}$ for varying periods. Favourable results following such saturation were reported by Albrecht (1938) and Weber (1938), but these findings were not confirmed (Erwin, Wright and Doherty, 1940; Bogen, Hawkins and Bennett, 1941), although numerous workers have reported success in intestinal and mucous membrane tuberculosis, both experimentally and clinically, following the administration of excess vitamin C. It would seem logical, on general principles, to correct any vitamin deficiency which may be discovered and, particularly during war time, when natural sources of vitamin $\mathrm{C}$ are not so readily available, it is advisable to prescribe the synthetic product. Where there is reason to suspect a deficiency of other vitamins, such deficiency may be made good by the prescription of concentrates, but there does not seem to be any necessity to exhibit these as a routine measurc.

A balanced diet should ensure also a sufficiency of minerals. The 2 pints of milk allotted daily provide sufficient calcium, and there is no definite evidence that calcium administered as a supplement has any real effect in increasing the deposition of the salt in the lung tissue or in any way expediting recovery.

From the clinical view point there is no great difficulty or mystery attached to the question of diet and tuberculosis. No special measure is necessary beyond the provision of an adequate supply of food, balanced in the correct proportions, but those who treat the tuberculous case know the great importance of presenting the food in a form which will appeal to the palate. The average tuberculous patient is inclined to be capricious as regards his food. His appetite is sometimes fickle, particularly after a prolonged period of bed rest or when he has been running a low grade fever for some weeks. Often, too, he has his own ideas on his diet, and these individual prejudices are not easily overcome. Meal times are major events in his day, and he surveys his provender with a hypercritical eye. Every effort should be made to see that it will survive such scrutiny successfully, for if he cannot be prevailed upon to eat his meal, its calorie content is of little account. It is necessary, therefore, to avoid monotony in the diet, to ensure good cooking and to see that the food is served as attractively as circumstances will permit. Care should be taken not to nauseate the patient by overloading the plate; rather should a small helping be given with a reminder that a second may be had for the asking. 
These points may seem minor ones and perhaps not particularly relevant to the subject under discussion, but they are, nevertheless, of supreme importance when one comes down to dealing with the actual patient and, as such, deserve inclusion in any remarks on the clinical position.

This brief survey of the clinical position would be incomplete without some reference to war and the dietetic restrictions which are imposed upon us as a result. Accustomed as we were to first class proteins in abundance, to unlimited butter and to cream, the introduction of rationing and the absence of concessions to the tuberculous, apart from milk, appeared calamitous. The average patient could not believe at first that any national emergency could justify a limitation of his meat and butter supplies, and the general attitude was one of resentment and alarm. Accommodation to the substitute fare was slow, and during the months when a more Spartan regime was being inaugurated there was a distinet fall in appetite. The quantity of food was adequate, the calories were there and the diet was sufficiently well balanced to supply all needs, but the stomach of the tuberculous patient is an ultra-conservative organ, and the fact that unaccustomed dishes were being offered caused a general all round reduction in the amount of food consumed. Gradually, however, and aided by the arrival of patients from the outside world, it was borne in upon them that the altered diet was not part of a deliberate plan to deprive them of their rights, and thereafter appetite began to return. Since then restrictions have been accepted cheerfully, and the survey of the results of treatment during the war years does not suggest that the dietary modifications have exercised any deleterious effect whatever on the treatment of the disease. The nutrition of the patient has been maintained, if gain in weight may be taken as a criterion of progress with due regard to its limitations in that respect. The charts reproduced in Figure 1 show the gain in weight recorded by the average patient in Tor-na-Dee during the years 1938 to 1942 . In 1938 and 1939 , when a full and unrestricted diet was being given, a steady gain was maintained month by month. In 1940 a steady gain was still recorded, although perhaps it was a little less striking than before, and towards the end of the year it began to decline. In December 1940 the average patient lost weight. In 1941, the transition period when the full rigour of rationing was really being felt for the first time, the average patient's weight suffered severely. The process of accommodation to the altered fare lasted about 7 or 8 months and then, with acceptance of the inevitable, appetites began to improve and the gain in weight recommenced. The 1942 figures show how fully accommodation had been achieved and how, on war time rationed diet with addition of the permitted 2 pints of milk daily, the average patient has gained weight just as steadily and to a greater extent than in 1938.

That this is not just a chance result or one confined to a particular sanatorium is shown by the investigations of Ross (1943) who, surveying the weight records of a series of patients in several of the Welsh sanatoria, reported that the average weight gained by the adult patients in 1942 was higher than that of 1938 . The weight gained by the children in 1942 was not quite up to the 1938 level, but fell short only by $0 \cdot 3 \mathrm{lb}$., which Ross regarded as satisfactory. These figures support the view that the war time diet is not deficient in nutritive properties as far as the voL. 3,1945$]$ 
tuberculous patient is concerned and that it contains everything which is necessary for the treatment of the disease. There is, however, no room in these circumstances for the indulgence of the dietetic whims and fancies of individual patients: most of them have learnt this lesson and their digestive systems have benefited as a result.



Figure 1.

As a corollary to the investigation of the weight records at Tor-na-Dee, the dispensary records for the years 1938 and 1942 were reviewed. These disclosed that in 194233 per cent. less alkaline powder and stomachics of various sorts were prescribed than in 1938, confirming an impression that under rationing there were fewer of the minor digestive symptoms and upsets usually associated with tuberculosis. It is possible that the introduction of sweet rationing has been beneficial in this respect, by removing the temptation, particularly among the female patients, to indulge in orgies of concentrated carbohydrates between meals to the detriment of both appetite and digestion.

So far the place of diet in the treatment of the disease has been considered, and it has been presupposed that the patient has been receiving his treatment in a sanatorium or hospital. At the conclusion of his institutional treatment he returns home, in many cases to a much less 
desirable environment, and the composition of his diet is then dictated not so much by his needs as by his economic circumstances. Nevertheless, his nutrition must be maintained, for he is still harbouring the tubercle bacillus and, strictly speaking, he has not finished treatment but merely entered upon another phase of it. The patient who is in reasonable financial circumstances presents merely a minor problem at this stage. He may require advice on what to eat, but he will not need to be told how he is to obtain it. Among the low income group, however, the clinical and sociological aspects of the problem now become intermingled. The recent investigations of the National Association for the Prevention of Tuberculosis (undated) into the income and food expenditure of tuberculous households in war time disclosed that the allowances payable by Health Authorities under Memo. 266/T will be effective in enabling the patients to secure their standard diet in 70 per cent. of households otherwise below the standard. Advice as to diet must therefore be given carefully, the patient being shown how to spend the money at his disposal so as to obtain the best return in food value. It must be remembered that the more expensive proteins are a luxury, not a necessity, and it should be impressed upon the patient that he is not sacrificing his chance of health by his inability to purchase the choicest joints. Extra nourishment for those in need may be obtained by application to the local tuberculosis authority, and the general rule about the non-prescription of cod liver oil may be waived, as the post-sanatorium diet of the poorer patient is apt to be deficient in protective foods.

Finally there is the question of whether the dietetic restrictions of war time have been an aetiological factor in the rise in incidence of tuberculosis which has occurred since 1939. The literature from the last war provided evidence that rationing, particularly when the restriction of protein is severe (Faber, 1938, 2), does lead to an increase in tuberculosis incidence, but so far there have been few convincing facts brought forward to suggest that this has been of importance in Britain during the present war. Laidlaw and Macfarlane (1941), investigating the position in Glasgow, came to the conclusion that a combination of long hours, overtime, strain and ill spent leisure were the prime aetiological factors and that deficient diet played an insignificant part. Experience at Tor-na-Dee Sanatorium confirms these findings. A private sanatorium draws its patients from a section of the community in which malnutrition is not encountered, yet this section has not been spared in the rise in incidence of the disease. Inquiry into individual case histories has elicited a common denominator in increased hours of work, coupled with additional duties in Civil Defence Services or in voluntary organizations, with curtailment of hours usually devoted to rest. In no instance has dietary deficiency played an obvious part. In addition, the shortage of sanatorium beds and subsequent retention amongst the community of a constant reservoir of infection must be given full weight.

Further investigations on the subject will doubtless be made, and it may be that additional evidence will be found to suggest differently but, on the evidence before us to date, the present situation from the clinical standpoint can be summed up briefly in one sentence: the amount of food is adequate, the amount of rest inadequate, and potential sources of infection are relatively uncontrolled.

vor. 3,1945 ] 


\section{Referentohs}

Abbasy, M. A., Harris, L. J. and Ellman, P. (1937). Lancet, 233, 181.

Albrecht, E. (1938). Med. Klinik, 34, 972.

Bogen, E., Hawkins, L. and Bennett, E. S. (1941). Amer. Rev. Tuberc. 44, 596.

Day, G. (1942). Tubercle, Lond., 23, 215.

Erwin, G. S., Wright, R. and Doherty, C. J. (1940). Brit. med. J. i, 688.

Faber, K. $(1938,1)$. Tuberculosen $i$ Danmark. 3. Tuberculose og Ernaering. Copenhagen: Gyldendalske Boghandel.

Faber, K. (1938, 2). Acta tuberc. scand. 1, 287.

Faber, K. (1939). Ugeskr. Loeg. 101, 1148.

Heise, F. H. and Martin, G. J. (1936). Proc. Soc. exp. Biol., N.Y., 34, 642.

Hurford, J. V. (1938). Laneet, 234, 498.

Keers, R. Y. (1943). Tubercle, Lond., 24, 137.

Laidlaw, S. and Macfarlane, D. (1941), Brit. med. J. ii, 436.

National Association for the Prevention of Tuberculosis, Tavistock House North, Tavistock Square, London, W.C.1. (undated). Report of Joint Committee Set up to Enquire into the Income and Food Expenditure of Tuberculous Households in War-Time.

Ross, H. A. (1943). Tubercle, Lond., 24, 134.

Vignal, W. (1943-44). Proc. R. Soc. Med. 37, 113.

Weber, H. (1938). Wien. klin. Wschr. 51, 1191.

\section{The Progress of Eradication of Tuberculosis from Cattle in Great Britain}

Mr. J. N. Ritchie (Ministry of Agriculture and Fisheries, 99 Gresham Street, London, E.C.2)

Until 1935 there was no official scheme in Great Britain for the eradication of tuberculosis from cattle. A considerable amount of tuberculin testing had, of course, been done prior to that date and, in order to provide tubercle free milk, owners had been licensed to produce Certified and Grade A Tuberculin Tested milk since 1923 under the Milk (Special Designations) Orders. These Orders were designed only to ensure that the milk would remain free of infection by periodical testing and removal of reactors from among the cows, and did not provide a progressive means of establishing and maintaining tubercle free herds.

In 1925 an Order was introduced providing for slaughter with compensation of clinically affected animals, but this was not considered to be a contribution towards eradication. It simply provided a means of removing animals potentially dangerous to the public health.

In 1935 the Tuberculosis (Attested Herds) Schemes were introduced and were administered separately in Scotland until 1938 when an amended Scheme to cover England, Wales and Scotland came into force. The Schemes provided for tuberculin testing, free of charge to the owner, of herds which at their last two tests had contained no reactor. When the herd passed an official test and became attested the owner was bound to observe certain rules framed to reduce the possibilities of the re-introduction of infection to a minimum. The rules provided for the prevention of infection arising from contact with cattle on neighbouring farms directly or indirectly, or arising from contact with swine or any other source of infection on the farm. They dealt with shows and sales at which animals from attested herds may be included, and they dealt with the movement of eattle on to and off the premises. 
At a later stage, in order to assist herd owners to qualify their herds for attestation, provision was made for paying a contribution towards the cost of tests by the owner's veterinary surgeon under Departmental supervision. In order to qualify for this assisted testing the herd owner had to provide evidence that at a test carried out, not less than two months earlier, fewer than 10 per cent. of his herd had reacted. These herds were known as "supervised herds."

In order to encourage owners to eradicate tuberculosis a bonus has been paid. The bonus was intended to represent some recompense for the expenses incurred in clearing the herd of the disease, but it has been altered from time to time as the work progressed. It consisted generally of a payment of approximately ld. per gallon of milk sold through a Milk Marketing Board from milk producing herds, or £l per head of cattle in other herds. At first the bonus was given for an indefinite period; more recently it was restricted to a period of 3 years, and during this year it has been discontinued altogether. In addition, a quality premium has also been paid by the Milk Marketing Boards for milk from attested herds not licensed for the production of designated milk, and for T.T. milk. The present quality premium for milk from an attested herd is 1d. per gallon and for T.T. milk 4d. per gallon.

Up to the outbreak of war the Scheme made good progress. Naturally it was somewhat slow at first but gained impetus with time, since the establishment of a few herds in an area usually encouraged herd owners to emulate their more progressive neighbours. Progress was particularly rapid in south west Scotland, notably in Ayrshire, where there was already a number of tubercle free herds producing T.T. milk, and in South Wales, notably in Carmarthen. The figures in Table 1 will indicate the achievement up to the outbreak of war.

TABLE 1

Number of Atrested Herds in Britain

\begin{tabular}{|c|c|c|c|c|c|c|}
\hline & & Period & & $\begin{array}{l}\text { England } \\
\text { and Wales }\end{array}$ & Scotland & Total \\
\hline $\begin{array}{l}\text { 'Гo } \\
, " \\
, " \\
, "\end{array}$ & $\begin{array}{c}30 \text { th } \\
\text { ", } \\
, " \\
, "\end{array}$ & $\begin{array}{c}\text { December, } \\
\text { ", } \\
\text { September, }\end{array}$ & $\begin{array}{l}1935 \\
1936 \\
1937 \\
1938 \\
1939\end{array}$ & $\begin{array}{r}55 \\
192 \\
813 \\
3529(3149) \\
8146(5690)\end{array}$ & $\begin{array}{r}44 \\
222 \\
638 \\
1115(963) \\
2202(1027)\end{array}$ & $\begin{array}{r}99 \\
414 \\
1451 \\
4648 \\
10,348\end{array}$ \\
\hline
\end{tabular}

The figures in brackets indicate the number of supervised herds.

Up to September 1939, therefore, 10,348 attested herds had been established in Great Britain; in addition, 6717 were in the process of attestation and undergoing assisted testing.

On the outbreak of war it was decided to suspend the acceptance of fresh applications under the scheme, except from those owners whose herds were licensed for the production of T.T. milk. The intention was to proceed with the eradication in the existing supervised herds and to endeavour to maintain the freedom from disease of the attested herds already established. There has been a fluctuation in the numbers because some herds have been removed from the Attested voL. 3,1945$]$ 
Register and a few T.T. herds have qualified for addition. The figures for the war years show that the present number of attested herds very nearly represents the sum of the attested and supervised herds existing at the outbreak of war. Thus, in March 1944, there were 4028 attested. herds in England, 8588 in Wales and 3569 in Scotland, giving a total of 16,185 .

More recently the scheme has been re-opened to all owners of cattle and there has been a good response from some areas. No financial assistance in regard to testing is offered prior to attestation, and new entrants will not receive any bonus, but a quality premium of $4 \mathrm{~d}$. per gallon is now available for T.T. milk and there is already evidence of satisfactory response to this inducement.

It has been shown clearly that herds of cattle free from tuberculosis are generally more healthy than other herds, and that cattle from attested herds command a higher price in the market. This is appreciated by the majority of herd owners, yet it is equally evident that without the monetary inducement by bonus payment the number of attested herds would be much lower today.

It is not only of interest, however, to note the number of attested herds which have been established. It is important to appreciate the proportion of such herds to other herds in the country and to consider how the herds are distributed geographically. Out of a total cattle population of approximately $8,000,000$ there are about 600,000 cattle in attested herds and in addition there are some 20,000 cattle in herds licensed to produce T.T. milk. In the three areas, namely, the Welsh counties of Cardigan, Pembroke and Carmarthen; Ayrshire; and the County of Bute, which carry the highest number of attested herds, the proportion of attested to non-attested herds is in the neighbourhood of 60 per cent. At the other end of the scale, for instance, in the 5 English counties of Lancashire, Cheshire, the West Riding of Yorkshire, Derby and Stafford, there are 282 attested herds and there is a total of about 37,000 dairy herds in these counties.

What of the future? There can be no doubt that from every angle it is important to eradicate this disease from our herds. We are still slaughtering about 15,000 clinically affected animals annually and in 1943 paid about $£ 70,000$ in compensation. Besides the direct loss involved from that source, there is a tremendous loss, extremely difficult to assess and difficult for the farmer to appreciate, through infected cattle becoming less than 100 per cent. efficient either as milk producers, breeders or feeders. The amount of meat condemned as unfit for human consumption on account of tuberculosis is still about 80 per cent. of the total condemned throughout the country.

In 1939 it was decided that the whole question of the attested herds scheme and eradication would be reconsidered after the war. The Minister of Agriculture and Fisheries has the power to set up eradication areas so that area eradication is a probable development of the future.

Some years ago it was considered fairly good practice to select from a bunch of cattle those few which had passed a tuberculin test and to use them for the production of tubercle free milk. That was much better than depending on a clinical examination to ensure the freedom of the milk, but it falls very far short of the ideal in maintaining a herd free from 
the disease. It has been appreciated for many years now, that animals which have passed a test but have originated from a farm where infection exists may be in an incubative state but not yet allergic, and this is recognized in rules governing their addition to attested herds which require that they remain for 60 days in isolation and pass another test before entering the herd. A step forward from the freedom of the individual animal was the freedom of the entire herd, and this conception of tuberculosis control has been a great advance, but it is still less desirable than the conception of area freedom. Where the herd only is free, it is often difficult to isolate the animals from the stock of neighbours who are less progressive, and it is necessary to carry out frequent tests to ensure that the herd remains free of infection. It has been found that the practice of testing not less frequently than once a year must continue if herds are to remain tubercle free, and it will be appreciated that this frequent testing makes such demands on staff that it hinders progress. The only safe way to reduce the frequency of testing is to set up an eradication area and gradually, by the elimination of possible infection from that area, to test at longer intervals.

In the United States of America, where eradication has proceeded on an area basis, areas which show an incidence of reactors of under 0.5 per cent. are tested as infrequently as once in 3 years and, when the infection is as low as 0.2 per cent., the tests may be at intervals of from 6 to 9 years. Individual herds with reactors are, of course, tested at short intervals until infection is again eliminated. By this method the whole country is maintained practically free of bovine tuberculosis with a relatively small proportion of the effort involved in our present methods. During the year to June 30 th, $1943,9,308,936$ cattle were tested in the United states and 0.18 per cent. reacted.

I had the opportunity recently to study the methods adopted in the United States at first hand, and the achievement of eradicating the disease from that country is a remarkable one. No other country has been able to reach such freedom from infection and great credit is due to all those who took part in the eradication campaign.

It may be of value to compare the conditions obtaining in the United States with those in this country. The U.S.A. has usually had a surplus or a near surplus of cattle and no real danger of serious interference with the meat or milk supply was to be feared when slaughtering reactors, and consequently the test could be applied over wide areas simultaneously; and in fact eradication was completed between 1917 and 1941. If this is compared with the position in Great Britain over the same period, it will be appreciated that this point alone provides a very obvious reason for a different rate of progress in eradication in the two countries and suggests that when more active measures are introduced here, it would be foolhardy to attempt to test cattle in numerous large areas at the same time. Smaller areas must first be cleared to provide adequate replacement cattle. In the States at times, and particularly during the depression years, the price of cattle reached an extremely low level. During such periods it is easy to pay for reactors and the farmer was glad of a market of any kind for his cattle. In this country, though prices have fluctuated, they have never reached such low levels. The incidence of infection in the two countries is, of course, very different. In the U.S.A. vor. 3,1945 ] 
the average incidence never got beyond 6 per cent., chiefly for the reason that it was mostly new country, although the incidence was in the region of 26 per cent. in New York State. In this country, the incidence is very much higher. The estimate usually quoted is that 40 per cent. of cattle are infected and it is certainly false, based as it is on slaughterhouse figures and not on tubereulin tests, but it may be correct to say that about 40 per cent. of cows are affected. Whatever the position may be, it is clear that the percentage of reactors in this country is so markedly higher than it was in America that the problem of eradication is entirely different. The situation in New York State most nearly approaches the situation here. In that State approximately 1,000,000 cattle had been slaughtered as reactors between May 1918 and October 1937, and in one county where the incidence was particularly high the total number of animals slaughtered in that period was equal to the total cattle population of the county.

Another factor which influenced the position in the United States was that there was a far greater demand outside the purely farming interests for eradication. The large packing houses were insistent that something should be done to reduce the loss from this particular disease. Many large cities introduced milk ordinances which required that the milk supply to the city should come from tubercle free cows and, besides this public health incentive, there was a definite drive from the milk industry, which represents a very considerable financial investment. In Great Britain there has been some incentive from the public health side but medical opinion has never been unanimous that eradication must proceed, and has sometimes been ill informed on the subject. The numerous butchers in this country could not speak with the influence at the command of the organized large packing houses of America. The milk industry has never launched any organized campaign for eradication. Funds have only recently been made available for the commencement of this important undertaking. In America, with the pressure from the representatives of these important farming and public health interests, it was not difficult to obtain adequate funds to meet each year's work.

All those men with whom I discussed the position in America were emphatic that progress really commenced with area eradication. This allows of testing a whole locality at one time and reducing at once the danger of infection to herds in the district. Cattle in the area require to be tested fairly often in the early stages, depending on the weight of infection found at the first test. When the area is free of infection there is no need for control of movement of stock within the area and owners are safe to allow contacts with neighbouring cattle which would have been inadvisable before.

It has been shown that the work which has been done so far in Britain has succeeded in removing tuberculosis from about 60 per cent. of herds in a few areas and there is now something of a reservoir of tubercle free stock for replacement of reactors, so that it is not unreasonable to suggest that area eradication might be found practicable in these districts.

It may be of interest to mention also something of the methods of testing which have been used in this and other countries. Great Britain is the only country which has consistently used the double intradermal test, which requires two injections of $0.1 \mathrm{ml}$. of tuberculin into the skin of the neck with an interval of 48 hours between them. A final observation 
of the result is made 72 hours after the first injection. In almost every other country a single injection is made, usually in the caudal fold, and only one post-injection observation is made. There have been difficulties with the tuberculin test. Up to 1940 the tuberculin used in official tests was a precipitated synthetic medium tuberculin which was eventually shown to give negative reactions in a number of cases where the animal was infected with bovine tuberculosis, and yet it was known from subsequent testing and post mortem examination of other reactors that this tuberculin occasionally produced positive reactions in animals which proved to be infected with organisms of the avian type. It was clear that while the tuberculin appeared to be of too low potency to remove as reactors all infected animals, there was also evidence that it was not specific. It was considered, however, essential to use a tuberculin which would disclose more nearly 100 per cent. of infected animals as reactors, and it was not anticipated that a more potent tuberculin would give a large number of anomalous results because of non-specific infections such as avian tuberculosis and Johne's disease. A tuberculin produced similarly to the one used in America was accordingly introduced in 1940 after extensive trial and comparison with the tuberculin formerly in use. After it came into general use it was shown, however, that there was a very much greater incidence of these non-specific infections than had been realized. As a result, since it is considered necessary only to remove animals infected with bovine tuberculosis from the herds, it was now a serious practical problem to evolve a method of testing which would differentiate between the reactors infected with bovine tuberculosis and those sensitized by organisms other than the bovine bacillus. After a good deal of experimentation, a comparative test using mammalian and avian tuberculins was adopted. This method of testing is still in operation and has been improved considerably. The tuberculins now used are P.P.D. (purified protein derivative) tuberculins and it is therefore simple to ensure that tuberculins of constant potency are used. This comparative test must be looked upon as a herd test, and its interpretation is influenced to a great extent by the picture of the prevalent type of infection present in the herd as indicated by the test results. In the light of experience, a method of interpretation has been evolved and has proved reasonably satisfactory. Frequently it is necessary to retest animals before a final conclusion can be reached. It is necessary to hold animals in isolation pending retest, but in practice farmers do not willingly hold animals isolated for long periods because of disturbance to farm routine. Although the most reliable retest results are probably obtained after 2 months' interval, in practice many retests are done at an interval of about one month. This point is montioned to indicate that there are occasions when farming practice and ideal procedure must be considered jointly in making arrangements under schemes of this kind.

Experiments are continuing in an attempt to produce a tuberculin which will be specific for bovine infection, but immediate results in this direction cannot be expected. It is anticipated that a form of comparative test will be essential in view of the amount of non-specific sensitization among cattle in Britain but it is hoped that simplification of the test may be looked for in the direction of a single injection of each tuberculin with only one post-injection observation.

vox. 3,1945$]$ 


\title{
Tuberculosis and Pasteurization of the Milk Supply
}

\author{
Mr. C. H. Chalmers (Department of Health for Scotland, St. Andrew's \\ House, Edinburgh)
}

\section{Introduction}

The subject of tuberculosis and pasteurization of the milk supply is so closely linked with the policy of encouraging increased consumption of milk, that some reference might first be made to this aspect of the subject.

Since 1939 the consumption of milk in Scotland has increased by over 30 per cent. and since 1934 by over 52 per cent. (Wilson, 1944). The war time increase in consumption is due in large measure to the introduction of the National Milk Scheme and to the stimulus by Health, Agriculture and Education Departments to the Milk-in-Schools Scheme. The most recent figures show that in Scotland just over 500,000 children, or 68 per cent. of those on the registers for all schools under the Local Authorities, are participating in the Milk-in-Schools Scheme and that these children are consuming about 450,000 gallons of milk a month. The National Milk Scheme, although only introduced in 1941, is equally successful, and it is estimated that 75 per cent. of those persons who are eligible, namely, the pregnant and nursing mothers, and children under 5 years of age, are taking advantage of the Scheme.

The Medical Research Council in its report of the Committee on Tuberculosis in War-Time (1942) suggests that the present daily consumption of milk per head of the population, namely, 0.4 to 0.5 pint, is inadequate and that for satisfactory nutrition this consumption should be increased to not less than 0.75 pint. To attain this object in Scotland it would be necessary for milk production to be increased by at least 35 million gallons during the winter 6 months of the year. The magnitude of this task is apparent.

The increased consumption, and probable further increase in consumption, of milk necessitates the drawing of milk for large urban areas from farms which are increasingly further from the centres of consumption. This involves not only transport difficulties, which the conditions of war have aggravated, but necessitates the bulking in the areas of production of milk of many producers.

Although there has thus been an increase in the amount of milk bulked and brought from areas remote from the main consuming centres, any resulting danger has been offset by a corresponding increase in the heat treatment of milk before despatch to the consuming centres.

The Extent of Infection of Milk with Mycobacterium tuberculosis

The figures which are available for the years 1939 to 1943 tend to show that the infection of ungraded raw milk from individual farms is decreasing. The incidence in different areas varied from $2 \cdot 0$ per cent. to just under 6.0 per cent. The infection of Certified and Tuberculin Tested milk was very rare. An accurate estimate of the extent of infection of the milk supply with tubercle bacilli during the war years cannot be made as the information available is not sufficiently detailed or extensive. There can, however, be no doubt that the infection of churn 
milk from individual farms must be considerably less than in pre-war years, due to the increase in the number of tubercle free herds in the country. In 1937 the number of Tuberculin Tested herds in Seotland was 769 and the estimated annual yield of milk from these herds was $19,741,000$ gallons. In July 1944 the number of Tuberculin Tested herds had increased to 2843 and the estimated annual yield of milk to approximately 50 million gallons.

The figures which are available relating to samples of milk sold as "pasteurized" during 1943 show that all the samples were negative to the biological test. The improvements which have been effected in pasteurizing equipment during recent years combined with a greater appreciation by dairymen of the value of pasteurization, must inevitably result in a higher proportion of "safe" milk reaching the consumer.

\section{The Extent to which Milk is Pasteurized or Heat Treated in Scotland before Consumplion}

The extent to which milk is heat treated or pasteurized before sale varies greatly in different areas. In the larger urban areas the percentage is over 80 but in some rural areas it is very low. It has been suggested that the high incidence of bovine tuberculosis in some country districts is due to this cause. Griffiths and Smith (1940) pointed out that in the rural area of Aberdeenshire the percentage of pulmonary tuberculosis due to the bovine bacillus is twice as high as in the city of Aberdeen where over 80 per cent. of the milk sold is pasteurized or heat treated.

The Effect of Pasteurization and Heat Treatment on Mycobacterium tuberculosis

The destruction of Mycobacterium tuberculosis in milk by heat depends not only on the temperature to which the milk is heated but also on the time during which the milk is exposed to any particular temperature. In other words it is a time temperature effect. Further, the rate of destruction of the organisms proceeds logarithmically and consequently the time taken to reach complete sterility is dependent also on the initial numbers of organisms present. The greater the initial contamination the longer is the time taken at any particular temperature to effect sterility or complete destruction of all the organisms present.

Many experiments have been carried out to determine the minimum function of time and temperature for destruction of Mycobacterium tuberculosis and it is now firmly established that a temperature of $60^{\circ} \mathrm{C}$. $\left(140^{\circ} \mathrm{F}\right.$.) for a period of 15 to 20 minutes is lethal to the organism. As the temperature is increased the time of exposure can be shortened but sufficient evidenee is not available on the effect of high temperature short time exposures to permit final and definite conclusions. Mattick and Hiscox (1939) are of the opinion that tubercle bacilli in naturally infected milk are destroyed within 12 to 15 seconds at $71 \cdot 1^{\circ} \mathrm{C} .\left(160^{\circ} \mathrm{F}\right.$.). There is, however, a limit to the temperature to which milk may be heated. At temperatures of $76 \cdot 6^{\circ} \mathrm{C} .\left(170^{\circ} \mathrm{F}\right.$.) and beyond, with zero holding time, the fat globules of the milk become affected with the result that some fail to rise to the surface of the milk. In other words, the amount of cream which rises on the heated milk is much reduced. A similar effect is observed at lower temperatures when combined.with a definite holding time such as $72 \cdot 2^{\circ} \mathrm{C}$. (162 $\mathrm{F}$.) for 15 to 20 seconds. The change in the voL. 3,1945 ] 
nature of the fat globules may indicate that other changes have taken place in the milk about which, as yet, little is known. From the commercial point of view this failure of all the cream to rise is a distinct disadvantage, as the housewife judges the quality of the milk by its cream line.

The Milk (Special Designations) Orders require that milk which is to be sold as pasteurized must be heated to a temperature of $145^{\circ}$ to $150^{\circ} \mathrm{F}$. for at least 30 minutes or to not less than $162^{\circ} \mathrm{F}$. for at least 15 seconds. A reasonable margin of safety has, therefore, been allowed. This margin in the case of holder pasteurized milk may appear unnecessarily great as the tubercle bacilli are destroyed in 5 minutes at $145^{\circ} \mathrm{F}$. $\left(62 \cdot 8^{\circ} \mathrm{C}\right.$.) and in 2 minutes at $150^{\circ} \mathrm{F} .\left(65 \cdot 6^{\circ} \mathrm{C}\right.$. $)$. In practice, however, a wide margin of safety is desirable as, in the holder process, there is much opportunity for conditions to arise which give protection to the organism. In some types of plant, for example, froth readily accumulates on the surface of the milk in the holder. The temperature of this froth may be some degrees below that of the milk itself and thus organisms present may escape destruction. Thermometers and temperature control gear tend to get out of adjustment, with the result that the milk may be heated to a temperature slightly lower than is recorded by the instruments.

In the case of high temperature short time pasteurizing, that is, heating the milk to a temperature of not less than $162^{\circ} \mathrm{F}$. for at least 15 seconds, the margin of safety is less than with the holder process. Thermometers of a high degree of accuracy and sensitivity are required and special arrangements must be made to ensure that every particle of the milk is held at the required temperature for the necessary time. This is particularly desirable as the milk is not held in a static condition in the holder, but is allowed to flow continuously through it. Although mercury in steel thermometers for recording and controlling give a high degree of accuracy there is always a lag between the actual temperature of the milk and that recorded in the temperature control instrument. If this could be overcome, and research is at present proceeding, it would be possible to pasteurize at slightly lower temperatures without extending the holding time and, thus, to preserve the creaming ability of the milk while at the same time ensuring that the tubercle bacilli were destroyed.

The earlier plants which were installed for heat treatment or pasteurization of milk had as their primary object a reduction in the general flora of the milk with a view to improving the keeping quality of the milk. The public health aspect was to a large extent neglected. Scott and Wright (1935) made an extensive inquiry into the design, operation and efficiency of pasteurizing plants in Scotland under the general co-ordination of the Department of Health for Scotland. This inquiry showed that, while gross errors in design and operation of the plants were relatively rare, in matters of detail many plants were not satisfactory. "In eight of the nineteen plants inspected there was no means of accurately gauging the holding time and eight thermometers out of thirty which were checked showed errors greater than $3^{\circ} \mathrm{F}$. In a few instances gross defects were found in the design and/or operation of plants. Such defects were associated with the presence of living tubercle bacilli in samples of the pasteurized milk. Thirty-three positive samples were found out of 1092 pasteurized milks examined, that is 3 per cent." 
During an investigation by the Department of Health for Scotland (1933) into the extent to which milk in 4 Scottish cities contained tubercle bacilli it was revealed that, of 1243 samples of bulked milk treated in one city by the holder process, 2.8 per cent. were positive and, of 291 samples of bulk milk treated by the "flash" process, $8 \cdot 2$ per cent. were positive. Smith (1932) examined 379 samples of mill which had been heat treated in Aberdeen and found 6 per cent. to contain living tubercle bacilli. Of the samples 192 were from "flash" heating plants and of these $9 \cdot 8$ per cent. contained Myco. tuberculosis. Since these investigations were made the position has much improved. In Glasgow during the years 1934 to 1937 not one of 497 samples of pasteurized milk examined proved to be infected. It is probable, however, that these samples were taken only from plants operating under licence and supervision of the Local Authority.

It may be concluded therefore that, provided the milk is heated in a plant of proper design and the plant is efficiently operated, pasteurization will destroy the tubercle bacilli. There is still, however, in Scotland a considerable number of heat treatment plants in use which do not possess efficient mechanisms to control the time and temperature and consequently these plants do not give consistently satisfactory results. These plants are fortunately being gradually replaced by modern plants of the H.T.S.T. type. Since 1941, 30 such plants have been installed or are in process of being installed in Scotland and are capable of treating 30,000 gallons of milk an hour.

\section{The Phosphatase and Coliform Tests}

There is little doubt that one of the greatest advances which have been made to determine the efficiency of heat treatment of milk from the public health aspect is the introduction of the phosphatase test. This test was the result of Kay and Graham's (1935) work on the enzyme phosphatase which occurs naturally in cow's milk. These workers showed that this enzyme is destroyed less readily at all combinations of time and temperature normally used for the heat treatment of milk than Myco. tuberculosis. The activity of this enzyme in milk can be readily detected by adding disodium phenyl phosphate to the milk and, after a short period of incubation, measuring the amount of phenol which the enzyme has liberated under a standard set of conditions. If milk is heated to a combination of time and temperature sufficient to destroy 98 per cent. of the activity of the enzyme it may safely be concluded that the heating has completely destroyed the tubercle bacilli.

The extent of the destruction of the activity of the enzyme is a function of time and temperature of exposure and not of one of these factors alone. By the use of this test, therefore, small errors in either the time or the temperature to which the milk has been heated can be detected. Moreover, because the enzyme is abundantly present in raw milk, the addition of small amounts, as little as 0.2 per cent., of unheated or inefficiently heated milk, caused through leaking valves and similar faults in the apparatus, to efficiently pasteurized milk can be readily detected.

The test has proved invaluable in demonstrating minor faults in pasteurizing plants which, according to the time and temperature recording apparatus, were working efficiently. The detection of these minor faults has caused manufacturers of pasteurizing plants to re-design parts of voL. 3,1945 ] 
their plants and equip them with recording and control apparatus which are more sensitive and reliable.

The destruction of the enzyme, however, only ensures that the milk as it leaves the heat treating portion of the pasteurizing plant has been efficiently treated. It does not indicate that the heat treated milk as sold to the public is free from pathogenic organisms. Post-pasteurizing contamination may arise from the bottling machine, the bottles, or the persons handling the milk. This contamination can, however, be detected by the coliform test. Coliform organisms are destroyed by efficient pasteurization but are invariably present on non-sterile surfaces of the milk plant and equipment. Their presence, therefore, in pasteurized milk which passes the phosphatase test is strongly indicative of post-pasteurizing contamination. The use of these two tests together will undoubtedly do much to improve the safety of pasteurized milk sold to the public.

\section{The Trend of Future Policy}

There can be little doubt about the desirability of encouraging increased consumption of milk by all sections of the community and especially by the children and necessitous persons, provided the milk is free from all pathogenic organisms, particularly Myco. tuberculosis.

To encourage the production of T.T. milk the Government has agreed to the payment of a premium of $4 \mathrm{~d}$. a gallon to all registered producers of T.T. milk. This has been a great stimulus and, since its introduction in October 1943, the number of Tuberculin Tested herds in Scotland has increased by 644 , or 29 per cent. Some time must, however, elapse before all the milk produced in the country is of tuberculin tested grade.

More recently an Order has been made under the Defence (General) Regulations permitting only pasteurized, heat treated or T.T. milk to be sold in certain specified areas. Pasteurized or heat treated milk sold in such areas will require to pass the phosphatase test and also a test for keeping quality. So far the Order has not been brought into force in any area but it will be applied as soon as the necessary arrangements can be completed.

Prior to the introduction of this Order there was no standard with which heat treated milk had to comply while pasteurized milk had only to satisfy a bacterial count. The requirement that both pasteurized and heat treated milk must pass the phosphatase test is a definite advance and will give a large measure of assurance that the milk sold in "specified" areas will be free from pathogenic organisms.

\section{Summary}

The policy of encouraging increased consumption of milk has been accompanied by efforts to increase the number of attested herds and to improve the quality of the milk supplied for consumption raw or heat treated. The evidence shows that"the infection of milk is decreasing and the efficiency of heat treatment increasing. Further developments along existing lines will still further safeguard the future position. 
Committee on Tuberculosis in War-Time (1942), Spec. Rep. Ser, med. Res. Coun., Lond., no. 246.

Department of Health for Scotland (1933). Spec. Rep. Ser. med. Res. Coun., Lond., no. 189.

Griffiths, A. S. and Smith, J. (1940). Lancet, 239, 291.

Kay, H. D. and Graham, W. R. (Jr.) (1935). J. Dairy Res. 6, 191.

Mattick, A. T. R. and Hiscox, E. R. (1939). Med. Offr, 61, 177.

Scott, A. W. and Wright, N. C. (1935). Bull. Hannah Dairy Inst, no. 6.

Smith, J. (1932). J. Hyg., Camb., 32, 354.

Wilson, G. (1944). Proc. R. phil. Soc. Glasg. 68, 148.

\section{Discussion}

Dr. S. I. A. Laidlaw (598 Shields Road, Pollockshields, Glasgow, S.1): I have probably been asked to open the discussion first because Glasgow is, at present, the black spot in Scotland, at least as far as notifications of tuberculosis are concerned, and the Glasgow records must materially affect the national figures.

Notifications of pulmonary tuberoulosis in Glasgow for the 5 years before the war have averaged about 1650 per annum and there has been a steady rise during the war years to 2778 in 1943 . The non-pulmonary tuberculosis notifications have increased much less, from just under 600 to 760 annually. The death rate from pulmonary tubereulosis has not risen in proportion to the notifications but only from about 1000 to 1100 annually. The reason for this is difficult to find. Dr. Westwater's suggestion that the excess of notifications is due to the work of the military medical boards does not hold in Glasgow, where only 10 per cent. of the notifications came from military boards, nor has it been due to mass radiography, which has produced only a very small proportion of the cases. There has been a real increase in phthisis morbidity in the civilian population in adults and children.

The low proportion of deaths has not been due to better treatment, for many doctors have been called up and the standard of nursing has not been raised. Housing has deteriorated and the weather has been bad.

There is one feature of great interest, namely that the acute bronchopneumonic type of case has decreased in frequency. Meningeal tuberculosis has increased by about 50 per cent. over pre-war level, and a large proportion of meningeal infections has been traced to infection by persons with positive sputum in overcrowded houses, especially in the east end.

Since the war began the Corporation of Glasgow has provided 600 additional beds for tubercular patients, making a total of 2050 . There is little possibility of increasing this number, despite the growing waiting list, because of shortage of nurses. Hence, it has been necessary to treat certain selected cases by artificial pneumothorax, as out patients. This group has been kept in hospital for only 2 or 3 days, and then allowed to return home, after which they come back periodically to the dispensary for refills. This has been much more successful than critics expected.

With regard to diet, the food supply in tuberculosis hospitals is satisfactory as regards calorie supply, but it must be remembered that relatives supplement the hospital diet to a considerable extent by bringing in food. I agree that patients, as a whole, gain weight. The war time diet in voc. 3,1945$]$ 
Committee on Tuberculosis in War-Time (1942), Spec. Rep. Ser, med. Res. Coun., Lond., no. 246.

Department of Health for Scotland (1933). Spec. Rep. Ser. med. Res. Coun., Lond., no. 189.

Griffiths, A. S. and Smith, J. (1940). Lancet, 239, 291.

Kay, H. D. and Graham, W. R. (Jr.) (1935). J. Dairy Res. 6, 191.

Mattick, A. T. R. and Hiscox, E. R. (1939). Med. Offr, 61, 177.

Scott, A. W. and Wright, N. C. (1935). Bull. Hannah Dairy Inst, no. 6.

Smith, J. (1932). J. Hyg., Camb., 32, 354.

Wilson, G. (1944). Proc. R. phil. Soc. Glasg. 68, 148.

\section{Discussion}

Dr. S. I. A. Laidlaw (598 Shields Road, Pollockshields, Glasgow, S.1): I have probably been asked to open the discussion first because Glasgow is, at present, the black spot in Scotland, at least as far as notifications of tuberculosis are concerned, and the Glasgow records must materially affect the national figures.

Notifications of pulmonary tuberoulosis in Glasgow for the 5 years before the war have averaged about 1650 per annum and there has been a steady rise during the war years to 2778 in 1943 . The non-pulmonary tuberculosis notifications have increased much less, from just under 600 to 760 annually. The death rate from pulmonary tubereulosis has not risen in proportion to the notifications but only from about 1000 to 1100 annually. The reason for this is difficult to find. Dr. Westwater's suggestion that the excess of notifications is due to the work of the military medical boards does not hold in Glasgow, where only 10 per cent. of the notifications came from military boards, nor has it been due to mass radiography, which has produced only a very small proportion of the cases. There has been a real increase in phthisis morbidity in the civilian population in adults and children.

The low proportion of deaths has not been due to better treatment, for many doctors have been called up and the standard of nursing has not been raised. Housing has deteriorated and the weather has been bad.

There is one feature of great interest, namely that the acute bronchopneumonic type of case has decreased in frequency. Meningeal tuberculosis has increased by about 50 per cent. over pre-war level, and a large proportion of meningeal infections has been traced to infection by persons with positive sputum in overcrowded houses, especially in the east end.

Since the war began the Corporation of Glasgow has provided 600 additional beds for tubercular patients, making a total of 2050 . There is little possibility of increasing this number, despite the growing waiting list, because of shortage of nurses. Hence, it has been necessary to treat certain selected cases by artificial pneumothorax, as out patients. This group has been kept in hospital for only 2 or 3 days, and then allowed to return home, after which they come back periodically to the dispensary for refills. This has been much more successful than critics expected.

With regard to diet, the food supply in tuberculosis hospitals is satisfactory as regards calorie supply, but it must be remembered that relatives supplement the hospital diet to a considerable extent by bringing in food. I agree that patients, as a whole, gain weight. The war time diet in voc. 3,1945$]$ 
hospital is monotonous and tho patient has not the advantage of being able to dine outside from time to time, which not only supplements one's rations but reduces the monotony of the ordinary ration. The only extra ration allowed the tuberculous patient is 2 pints of milk daily. In my opinion the allowance of meat should be doubled and the fat ration increased for tuberculous patients. I feel sure that additional protein would aid the patient's recovery. Mince is in great demand among city patients.

As regards the outlook for the future, tuberculosis will always be a problem in Glasgow while housing is bad. Even when patients are rehoused, if they are placed at such distances from the town, and at such higher rents that money for rent and travelling has to be deducted from that spent on food, conditions will still not be satisfactory.

In my opinion, modern young women are not interested in cooking and this makes national restaurants more important. Public tasto might be influenced by lowering the prices of the dishes or meals considered specially nutritious and raising the price of popular dishes, the sale of which the dietetic experts wished to curtail.

Dr. W. M. Mackay (Ministry of Agriculture, Drumblair House, Forgue, Aberdeenshire): In dairy herds before the war, when agriculture was in such a depressed state, the majority of the cows was far too old. Once Tuberculin Tested herds have been established, it may be possible to have animals of all ages in a herd, but in the average ungraded herd, the majority of open cases of tuberculosis occurs after about the age of 6 years. No cow in an ordinary ungraded herd should be kept after the age of 5 . A regulation to this effect would speed up the elimination of tuberculous milk.

In dairy herds, housing appear's to have very little effect on the incidence of elinical tuberculosis. Large numbers of open cases of tuberculosis are found in good buildings. Very often the poor crofters' byres show a better picture.

The estimate of 40 per cent. incidence of tuberculosis, quoted by Mr. Ritchie, applies only to dairy cows. In the beef herd, with an average age of about 3 years, clinical tuberculosis is seldom scen. Cases are usually found only at post mortem and, although the extent of the infection may then be great, there is seldom any sign before slaughter. Almost all the clinical cases are found in dairy herds and once clinical signs have developed, often following the birth of a calf, the life of a cow is seldom more than 1 or 2 months. Chronic tuberculosis, as it is known in man, seldom appears in the bovine.

Dairy herds might be described as pathological institutions because the cows are constantly lactating or pregnant or both. The high yielding cow seems unable to hold her own after 3 or 4 lactations. The fourth pregnancy may be followed by a rapid deterioration in condition and, within a month, sometimes within a week, the cow is at the point of death from tuberculosis.

The difference between dairy herds and beef herds is not entirely due to the sex difference but, even in the becf herd, females will account for about 65 per cent. of the gross cases of abattoir tuberculosis, and males for only 35 per cent. Sox does, therefore, appear to play some part in determining the cxtent of spread of the disease in the individual. 
It was for long accepted and may still be accepted that in utero infection with tuberculosis rarely occurs in man. That is certainly not true of the bovine. In a recent investigation, a thorough post mortem examination of foetuses from tuberculous cows revealed cases with advanced lesions, including calcified tubercles in the liver, spleen and mediastinal glands.

Mr.J. Gerrie (2 Queen's Gardens, Aberdeen): There has been an increase in tuberculous otitis media in very young children. The disease causes extensive damage to the middle ear and mastoid, with facial paralysis, glandular enlargement on the affected side, and, if not dealt with adequately, results in death. It has been supposed that this type of infection is due to direct infection from tubercle infected milk, especially when given to infants from a bottle, with the infant lying on its back. The source may occasionally be human, although there is no confirmatory evidence. Tuberculous infection of the adenoids almost always occurs in association with the ear condition.

Professor W. J. Tulloch (University of St. Andrews Medical School, Dundee): When did the investigation of meningeal tuberculosis begin?

Dr. Westwater: An investigation began in Scotland for the Medical Research Council in 1942 and is still continuing. There might be a report after the end of this year. In cases of meningeal tuberculosis the type is being investigated. The meningeal form indicates recent infection.

Dr. Munro: It is not easy to prove infection of cattle by the human subject. I myself have seen one instance of bovine type tuberculosis reintroduced by an infected cattleman into a herd which was being established as free.

Regarding the immunization of the human subject by small doses of tubercle in milk, the view that such a form of immunization should be practised fails entirely to take account of the fact that bovine tuberculosis, not human, is the virulent type, that the dosage is totally uncontrolled and that disaster might attend the experiment at any moment. Such attempts at immunization are extremely dangerous.

Bovine tuberculosis is most dangerous in rural areas, on the small one or two cow holdings, in ploughmen's children. There it should be scheduled as an industrial disease; it can scarcely be avoided in the nature of the occupation. The children can be identified as ploughmen's children long after, in other occupations, in cities, when the lesions acquired in childhood break down.

Dr. I. Leitch: On the question whether milk is a good or necessary food for adults, about two-thirds of the dietary calcium comes from milk, including cheese. If the amounts now advocated as optimum intakes are desired, it is very difficult indeed to get them without milk. Has Dr. Keers made any observations on fat intolerance in relation to susceptibility to tuberculosis? It has been suggested that, within a family where infection is present, members who dislike or have an intolerance to fat are those who develop clinical tuberculosis. Can Dr. Keers say whether the popular slimming campaign in recent years is thought to have had any effect on the incidence of tuberculosis, particularly on the stasis of the mortality rate in young adult females?

voL. 3,1945 ] 
Dr. Keers: I have no definite evidence that fat intolerance predisposes to the development of tuberculosis but the possibility is not excluded. I believe, and the view is widely held, that slimming has had a definite effect on the incidence of tuberculosis in young adults.

Dr. Munro: With regard to the relationship of diabetes to tuberculosis, the diabetic is more liable to develop the disease but, under adequate insulin treatment, diabetics do as well as, or better than, other patients.

Professor R. C. Garry (University College, Dundee): In view of what Dr. Munro has said, has insulin ever been used in the treatment of nondiabetic cases?

Dr. Munro: Himsworth (1938) claims that insulin gives favourable results.

\section{REFERENCE}

Himsworth, H. P. (1938). Quart. J. Med. 31, 373.

Dr. Keers: Day (1942) also claims beneficial effects. This work however requires confirmation because, although the patients made good gain in weight under insulin treatment, the gains were lost when treatment stopped.

REFERENCE

Day, G. (1942). T'ubercle, Lond., 23, 224.

Dr. Munro: I would put the three most important parts of treatment in this order: first rest, second good food and third adequate ventilation.

Mr. Ritchie: On the question of the degree of infection of herds and of the infection of cattle by human subjects, the human and avian types of organism would not be expected to cause lesions in cattle, although they might sensitize them to the tuberculin test. Only the bovine organism would normally produce disease that would progress. 